\title{
Çerkeşşeyhizâde Mehmed Tevfik Efendi'nin Tevhîd Anlayışı
}

\author{
İbrahim Bayram \\ Doç. Dr., Tokat Gaziosmanpaşa Üniversitesi İlahiyat Fakültesi, Kelâm Anabilim Dalı \\ Asssociate Professor, Tokat Gaziosmanpaşa University, Faculty of Theology, Department of Kalām \\ Tokat, Türkiye \\ ibrahim.bayram@gop.edu.tr \\ ORCID 0000-0002-4752-0447
}

\section{Çerkeşseyhizâde Mehmet Tevfik's Understanding of Tawhīd}

\begin{abstract}
Çerkeşşeyhizāde Mehmed Tevfik Efendi (Cherkessheyhi-Zāde Mehmed Tawfíq Afandī), who is one of the important figures of the recent Ottoman ulama, was born in Ankara in 1242/1826 as the son of a family with knowledge and tasawwuf. After receiving his first education in the city where he was born, he moved to Istanbul, where he followed the lessons of scholars such as Vidinli Mustafa Efendi (Vidinli Mușțafā Afandī) and Hafız Seyyid Efendi (Ḥăfiẓ Sayyid Afandī) and received ijazat from them. He served as a Mawlawiyāt Qadi (the highest judge/qadi) in various parts of the empire, served as a qadi in Madinah, then returned to Ankara and became a professor. Apart from these, he also served in various positions, and was awarded with the rank of Anatolia and then Rumelia Qādí-'askar (highest ranking qadi's of the Ottoman judiciary) in 1899, respectively. He died in 1901 and was buried in Aksaray, Istanbul.

Çerkeşşeyhizde Mehmed Tevfik Efendi, who left behind many works in the style of treatises in the fields of grammar (sarf), nahw (syntax), literature, health, fiqh, logic, philosophy, mysticism and kalām, expressed his views on the most fundamental issues of the Islamic faith. In this sense, he also expressed his opinions on tawhìd. He tried to prove the existence of the God (ithbat al-wajib), which he will reveal in unity in the way of entry, in this sense, he focused his explanations especially on the rankings of existence consisting of necessary, possible and impossible. He proved the necessity of a necessary being in a rational inferences by depending on the premises he created based on these concepts. After that, he tried to ground that necessity of the existence of a God, based on some verses that indicate the order in the universe.

While examining the subject of tawhìd, the he discussed its nature, the relation between dhāt (essence) and atributes, the possibility of the reason reaching this principle alone and also made an evaluation of the sudūr (emanation) theory of philosophers in the context of the idea of tawhid. Regarding these issues, he explained the tawhīd as the oneness of Allah about being wajib al-wujûd, creator and ma'bood. He also tried to prevent the jeopardise of the doctrine of tawhid by expressing that the attributes of Allah are neither the same nor the informal of His dhāt. He argued that the views put forward by Muslim philosophers in the framework of the understanding of sudūr doctrine cause the idea of the eternal of objects, by doing so they have distanced themselves from the understanding of tawhïd of Islam.
\end{abstract}

Intihal Taraması/Plagiarism Detection: Bu makale intihal taramasından geçirildi/This paper was checked for plagiarism Geliş/Received: 31 Aralık/December 2019|Kabul/Accepted:10 Şubat/Fabruary 2020|Yayın/Published: 20 Mart/March 2020 Atıf/Cite as: İbrahim Bayram, “Çerkeşşeyhizâde Mehmed Tevfik Efendi’nin Tevhîd Anlayışı = Çerkeşşeyhizâde Mehmet Tevfik's Understanding of Tawhīd”, Eskiyeni 40 (Mart/March 2020), 219-242. https://doi.org/10.37697/eskiyeni. 667866

Copyright @ Anadolu Illahiyat Akademisi/Anatolian Theological Academy, 06050, Ankara, Turkey | www.anilakademi.com CC BY-NC 4.0 | This paper is licensed under a Creative Commons Attribution-NonCommercial License 
The main issue on which he focused on was undoubtedly the proof of tawhìd. In this sense, he first urged His oneness based on the concept of wajib, which he included at the stage of proving Allah's existence. At this stage, first of all, he stated that the world needs a necessary being, considering that it is possible being. He then demonstrated the necessity of the wajib being by stating that the idea of His absence causes the dilemmas. Then, he stated that assuming the absence of a second hypothetical deity did not lead to any dilemma, and that it was understood that the wajib being must be only one. Çerkeşşeyhizāde Mehmed Tevfik Efendi focused mostly on the burhān al-tamānu' (proof of altamānu') among the proofs of tawhìd. The fact that it originated from the Qur'an and that the predecessor scholars gave weight to it seems to have been effective in this preference. This proof is a arguing the possibility of a conflict between them and its outcome if the existence of a hypothetical deity is accepted in addition to the existence of God. The author conveys the proof in this manner. According to this, if one of the gods wants the movement of a being and the other wants its quiescent, and both say it, this is not possible because it involves the meaning of something to carry on two opposite qualities at the same time. If neither of said fulfilled, this option is out of the question, as there will be an insolvency contrary to divinity. If only one order fulfilled and others didn't, in this case other's claim of deityness would weaken. Consequently the first being will be true god since his order fulfilled. The author has expressed his own opinion on whether or not this proof provides certainty. He also opined his objections to some scholars who misrepresent this evidence.

Another proof of tawhild given by the author on this subject is that mostly identified with the Imam al-Māturīì. According to this, the miracle shown by the prophet in order to his message is also prove the oneness of that God; while the other hypothetical deity's silence on this proves that the God is one. He also tries to demonstrate that the God's oneness based on a some of dilemmas such as ignorance and impotence, which arise if more than one deity claims sovereignty on different scopes. Nevertheless, he presents the options that if more than one deity is accepted, one of them will be either imperfect or equivalent to the other. He eliminates the first possibility with the thesis that the imperfect being cannot be a deity. The author states that if both gods are equal, the world either exist or not; if it exists, there would be conflict between both and this option is not possible as well, since it would eliminate the order of the world. According to him, all these possibilities revealed that God is one.

Apart from these proofs, the he also considers and examines the naturalist approach, which contains elements contrary to monotheism and the approach that attributes a son to God. He criticizes the first approach, which imposes a great mission on the concept of nature that contains more uncertainty and their explanation of the order in the universe through nature, which is lack of knowledge, perception and consciousness. As for the son attribute to God, he criticizes with the thesis that the son would be created being whether it is formed through semen or in some other way.

\section{Keywords}

Kalām, Çerkeşşeyhizâde Mehmed Tevfik Efendi, Cherkessheyhi-Zāde Meḥmed Tawfīq Afandī, Naturalists, Tawhīd, Proofs of Tawhīd, Argument of Tamānu

\section{Öz}

\section{Çerkeşşeyhizâde Mehmed Tevfik Efendi'nin Tevhîd Anlayışı}

Son dönem Osmanlı ulemasının önemli simalarından biri olan Çerkeşşeyhizâde Mehmed Tevfik Efendi, ilim ve tasavvuf ehli bir ailenin evladı olarak 1242/1826 yılında Ankara'da dünyaya gelmiştir. İlk tahsilini doğduğu şehirde aldıktan sonra İstanbul'a gelmiş, burada Vidinli Mustafa Efendi ile Hafız Seyyid Efendi gibi âlimlerin derslerini takip ederek onlardan icazet almıştır. İmparatorluğun çeşitli bölgelerinde mevleviyet görevlerinde bulunmuş, Medine'de kadılık yapmış, sonrasında Ankara'ya dönerek müderrislik yapmıştır. Bunların dışında çeşitli vazifelerde de bulunmuş, en son 1899 ylında sırasıyla önce Anadolu sonra da Rumeli Kazaskerliği payesi ile taltif edilmiştir. 1901 yllında vefat eden müellif, İstanbul Aksaray'da defnolunmuştur. 
Ardında sarf, nahiv, edebiyat, sağlık, fikıh, mantık, felsefe, tasavvuf ve kelâm alanında çoğu risale tarzında pek çok eser bırakan Çerkeşşeyhizâde Mehmed Tevfik Efendi, İslâm inancının en temel meselelerine dair görüş beyan etmiştir. Bu manada tevhîd konusunda da fikirlerini dile getirmiştir. 0 , tevhîde adeta giriş sadedinde önce birliğini ortaya koyacağı ilahın varlığını (isbât-ı vâcib) ispat etmeye çalışmış, bu manada açıklamalarını özellikle vâcib, mümkün ve mümteni kısımlarından oluşan varlıkmertebeleri üzerine yoğunlaştırmıştır. Bu kavramlardan hareketle oluşturduğu öncüllere bağlı olarak bir zorunlu varlığın gerekliliğini akli yoldan ispat etmiştir. Sonrasında evrendeki düzene delalet eden bir kısım âyetlerden yola çıkarak bir ilahın varlığının zorunlu olduğunu göstermeye çalısmıştır.

Müellif, tevhîd konusunu işlerken onun mahiyeti, zat-sıfat ilişkisi, aklın tek başına bu ilkeye ulaşmasının imkânını ele almış, ayrıca filozofların sudur teorisinin tevhîd düşüncesi bağlamında bir değerlendirmesini yapmıştır. Bu meselelerle ilgili olarak o, tevhîdi, Allah'ın vâcibü'l-vücûd, yaratıcı ve ma'bud olma hususunda birliği olarak açılamıştır. Yine Allah'ın sıfatlarının O'nun zatının ne aynı ne de gayrı olduğunu ifade ederek tevhîd düşüncesinin zedelenmesinin önüne geçmeye çalışmıştır. Bu konuda İslâm filozoflarının sudur anlayışı çerçevesinde ortaya koydukları görüşlerin cisimlerin kadimliği düşüncesini beraberinde getirdiği için onların İslâm'ın tevhîd anlayışından uzaklaştıklarını savunmuştur.

Onun bu konuda ilgisini yoğunlaştırdığı temel mesele ise şüphesiz tevhîd delilleri olmuştur. Bu manada öncelikle Allah'ın varlı̆̆ını ispat aşamasında yer verdiği vâcib/zorunlu kavramından hareketle O'nun birliğini ortaya koymaya çalışmıştır. Bu aşamada önce âlemin mümkün varlık olmasından yola çıkarak onun zorunlu bir varlığa ihtiyaç duyduğunu ifade etmiştir. Sonra da O'nun yokluğunu tasavvur etmenin açmazlara neden olduğunu belirterek vâcib/zorunlu varlığın gerekliliğini göstermiştir. Bu noktada O'nun kendisi gibi ikinci bir farazi ilahın yokluğunu düşünmenin ise hiçbir sıkıntıya yol açmadığını ifade ile o vâcib varlı̆̆ın bir olduğunun anlaşıldığını belirtmiştir.

Çerkeşşeyhizâde Mehmed Tevfik Efendi, tevhîd delilleri içerisinde en çok burhân-1 temânu deliliüzerinde durmuştur. Kur'ân kaynaklı olması, selef ulemanın da ona ağırlık vermesi müellifin bu tercihinde etkili olmuşa benzemektedir. Bu delil, varlığı zorunluğu ilahın yanında farazi bir ilahın daha varlığının kabul edilmesi halinde, aralarında çıkacak bir ihtilaf ihtimali ve bunun neticesi üzerinden ortaya konan bir kanıttır. Müellif de bu minvalde delili aktarır. Buna göre ilahlardan biri, bir varlığın hareketini, diğeri onun sükununu murat ettiğinde, ikisinin de dediği olursa, bu bir şeyin aynı anda iki zıt niteliği üzerinde taşıması anlamı içereceği için mümkün değildir. İkisinin de dediği olmazsa ilahlığa zıt acizlik durumu ortaya çıkacağı için bu seçenek de söz konusu olamaz. Şayet sadece birinin dediği olursa, diğerinin yine acizliği ortaya çıkı ilahlık iddiası ortadan kalkacağı için dediği olan ilah olur ve bu ilahlığında tek kalmış olur. Müellif, bu konuda ilgili delili aktardığı gibi onun kesinlik bildirip bildirmediği hakkında da fikir beyan etmiştir. Ayrıca bu delili yanlış aktardığını düşündüğü bazı şahsiyetlere yönelik itirazlarını da dile getirmiştir.

Müellifin bu konuda yer verdiği bir diğer tevhîd delili ise daha çok İmam Mâtürîdî ile özdeşleşen bir kanıttır. Buna göre bir olduğunu iddia eden ilahın peygamberi olan zatın, kendi davasını ispat için gösterdiği mucize, aynı zamanda o ilahın birliğinin de ispatı mahiyetinde iken, diğer farazi ilahın bu konuda sessiz kalması, ilahın bir olduğunu ispat eder. Müellif, birden fazla ilahın ayrı mülkler üzerinde ilahlık iddia etmesi halinde de ortaya çıkacak cehalet ve acizlik gibi birtakım açmazlardan hareketle ilahın bir olduğunu göstermeye çalışır. Yine birden fazla ilahın varlı̆̆ını kabul halinde önce onlardan birinin diğerinden ya eksik ya da diğerine denk olacağı seçeneklerini ortaya koyar. i̇lk ihtimali eksik varlığın ilah olamayacă̆ı teziyle devre dışı bırakır. Denk olması halinde ise, varlığını müşahede ettiğimiz âlemin ya varlık kazanamayacağını ya da olup da varlık kazanırsa bu kez ilahların arasında ihtilafın çıkacağını, bunun da âlemin nizamını ortadan kaldıracağı için onun da mümkün olmadığını ifade eder. Ona göre bunların neticesinde ilahın bir olduğu ortaya çıkar.

Müellif, bu delillerin dışında tevhîde aykırı unsurlar barından tabiatçı anlayışı ve ilaha bir evlat isnat eden yaklaşımı da ele alıp inceler. Bu manada ilk yaklaşımı daha çok belirsizlik içeren tabiat kavramına büyük bir misyon yüklemeleri ve evrendeki düzeni ilim, idrak ve şuur gibi özelliklerden uzak 
olan tabiat ile açiklamaları üzerinden eleştirir. Allah'a isnat edilen evladı ise o, ister bir nutfe aracıllğıyla isterse başka bir şekilde oluşsun, sonuç itibariyle burada mutlaka hâdisliğin gündeme geleceği teziyle tenkit eder.

Anahtar Kelimeler

Kelâm, Çerkeşşeyhizâde Mehmed Tevfik Efendi, Çerkeşşeyhizâde Mehmed Tevfik, Tabiatçılar, Tevhîd, Tevhîd Delillleri, Burhân-ı Temânu’

\section{Giriş}

İslam ile özdeşleştirilen, inanç konularını inceleyen bir kısım eserlere adı verilen, bir itikadî mezhebin ismi içerisinde yer alacak kadar kendisine değer atfedilen tevhîd ilkesi, bu önemine uygun şekilde geçmişten günümüze her daim akaid ve kelâm alanındaki çalışmaların ana mevzularından birini teşkil etmiştir. Bu doğrultuda Kur'an'da temelleri atılan, kelâm ilminde farklı veçheleriyle zenginleștirilen tevhîd konusu, her zaman önemini muhafaza etmiştir. Sadece teorik düzeyde ortaya konulmakla kalmayan, aynı zamanda pratik bir yansımasının da hayata aksettirilmesi amaçlanan tevhîd prensibi, şüphesiz bir Müslümanın hem zihin dünyasında hem de pratik hayatında vazgeçilmez bir role sahip olmuştur. İslam'ın bu konuda ortaya koyduğu tavra bakılacak olursa onun bu ehemmiyeti ilelebet devam edecektir.

İslam inanç esaslarının ilki olan ulûhiyetin en önemli ve özünde bir ittifak olmakla birlikte nelerin kendisini zedeleyeceği hususunda çeşitli ihtilafların bulunduğu tevhîd ilkesi, Kur'an ile başlayan bir ispat sürecine konu olmuştur. İslam uleması getirdikleri muhtelif delillerle bu sürece şüphesiz önemli katkılar sunmuştur. Bir kısmı âyetlerden hareketle tespit edilen ve çeşitli açıklamalarla zenginleştirilen delillerin diğer bir bölümü ise ileride örnekleri verileceği üzere daha farklı bir mahiyette ortaya konulmuştur. Bir yönüyle isbât-1 vâcib meselesi içerisinde yer alsa da tevhîd için ayrıca özel başlıklar açılmış ve hakkında başka deliller de üretilmiştir. Bu anlamda İslam düşüncesinde oldukça güçlü bir ilmi gelenek oluşmuş ve zengin bir tevhîdi delil manzumesi teşekkül etmiştir.

Bu ilmi geleneği devam ettiren zatlardan biri de son dönem Osmanlı âlimlerinden Çerkeşşeyhizâde Mehmed TevfikEfendi olmuştur. 1242/1826 yılında Ankara'da Çerkeşli Mustafa Efendi'nin (öl. 1229/1814) oğlu ulemadan Osman Vehbi Efendi'nin (öl. 1277/1860) çocuğu olarak dünyaya gelen Mehmed Tevfik Efendi, ${ }^{1}$ dedesinin doğum yerinden hareketle kimi kaynaklarda Çerkeşîâade; ${ }^{2}$ kendi eserlerinin bir kısmında Çerkeşişeyhizâde, ${ }^{3}$ bazısında ise Çerkeşşeyhizâde diye anılmaktadır. ${ }^{4}$ Ilk tahsilini babasından almış, ayrıca Ahaveyn Ahmed Efendi'den ders görmüştür. ${ }^{6} 1846$ yılında İstanbul'a gelmiş ve eğitimini burada sürdürmeye başlamıştır. ${ }^{7}$ Vidinli Mustafa Efendi ile Hafız

1 İbnülemin Mahmud Kemal İnal, Son Asır Türk Şairleri (İstanbul: Milli Eğitim Basımevi, 1970), 10/1873; Mehmet Zeki Pakalın, Sicill-i Osmanî Zeyli, haz. Mustafa Keskin vd. (Ankara: Türk Tarih Kurumu, 2008), $12 / 14$.

2 Bursalı Mehmed Tahir, Osmanlı Müellifleri (İstanbul: Matbaa-i Âmire, 1333), 1/271.

3 Çerkeşişseyhizâde Mehmed Tevfik Efendi, er-Risâletü'l-Hamidiyye (Kahire: el-Matbaatü'l-Behiyye, 1310.).

4 Çerkeşşeyhizâde Mehmed Tevfik Efendi, Miftâhu'l-akâid (İstanbul: Mihran Matbaas1, 1301).

5 İnal, Son Astr Türk Şairleri, 10/1873.

6 Sadık Albayrak, Son Devir Osmanlı Uleması (İstanbul: Milli Gazete Yayınları, 1981), 4/126.

7 Mehmed Tahir, Osmanlı Müellifleri, 1/271. 
Seyyid Efendi'nin derslerine devam etmiş ve icazet almıştır. ${ }^{8}$ Beşiktaş, Halep, Çankırı, Bursa, Balıkesir ve Mısır'da mevleviyet görevlerinde bulunmuş, sonrasında Medine'de kadılık yapmıştır. Ardından Ankara'ya dönmüş, burada on iki yıl müderrislik vazifesini yürütmüş, ${ }^{9}$ yirmi kişiye icazet vermiştir. ${ }^{10} 1877$ yılında Ankara mebusu olarak Meclis-i Mebûsân'a girmiş, 1883 yılı Ocak ayında Mahkeme-i Teftîş-i Evkâf Müsteşarlığına, aynı yılın Ağustos ayında ise İstanbul Kadılığına getirilmiştir. ${ }^{11} 1885$ yılında Aydın ilinin Çeşme kazasında vuku bulan bir ihtilafın çözümü için kurulan heyete başkanlık yapmıştır. ${ }^{12}$ Bir yıl sonra (1886) Rumeli Kazaskerliği muavinliğine ve Meclis-i Meşâyih Nazırlığına getirilmiştir. ${ }^{13} 1890$ yllında Tetkîk-i Müellefât Encümen Riyasetine seçilmiş, 1899 'da ise önce Anadolu Kazaskerliği; sonrasında da aynı yıl içerisinde Rumeli Kazaskerliği payesi ile ödüllendirilmiştir. ${ }^{14}$ 1319/1901 yılında Hakk'ın rahmetine kavuşan müellif, Aksaray'da bulunan Sofular Tekkesi içerisindeki Şeyh Ekmeleddin Dergâhı haziresine defnolunmuştur. ${ }^{15}$

Tasavvufi yönü yanında kelâmcı bir hüviyete de sahip bulunan Çerkeşşeyhizâde, muhtelif ilim dallarında eserler vermiştir. Bazı eserlerini Arapça, bazılarını da Osmanlıca olarak kaleme alan müellifin sarf, nahiv, edebiyat, sağlık, fıkıh, mantık, felsefe, tasavvuf ve kelâm alanında çalışmaları bulunmaktadır. Onun kelâm sahasını doğrudan ilgilendiren eserlerini Miftâhu'l-akaid, Meziyyet-i İslamiyye, el-İtkân fî tahkîki'l-imân, Risâle fi'l-akl, Şerh-i Akâid-i Nesefî Tercümesindeki Hatalara Dair Risale, Hudûsu'l-Âlem Risâlesi, Risâle-i fì kabûli't-tevbe ${ }^{16}$ ve Risâle fî mec'ûliyyeti'l-mâhiyye (Risâle fî mahiyeti'lmümkin ve'l-mec 'ûliyye ${ }^{17}$ şeklinde sıralamak mümkündür. Bazı eserlerinin isimsiz şekilde basılması, onlara konusundan hareketle bir ad verilmesine yol açmış, ancak bu durum bazı karışıklıklara neden olmuştur. Bu manada aynı eser farklı şekillerde isimlendirildiği için kimi zaman sanki iki ayrı telif gibi algılanmıştır. Bu çalışmada ise müellifin farklı isimlerle anılan kimi eserlerine atıf yapılırken, onlar için uygun olduğu düşünülen isimler zikredilmiş ve çalışma boyunca aynı isimlerin kullanılmasına dikkat edilmiştir.

8 [Çerkeşşeyhizâde Mehmed Tevfik Efendi], “Tercüme-i Sahib-i Hal-i Divan”, Kasâid-i Tevfik (ìstanbul: Mihran Matbaası, 1304), 47; İnal, Son Asır Türk Şairleri, 10/1873.

9 [Çerkeşşeyhizâde], “Tercüme-i Sahib-i Hal-i Divan”, 48; İnal, Son Astr Türk şairleri, 10/1873; Nihat Azamat, "Çerkeşî Mustafa Efendi”, Türkiye Diyanet Vakfi İslâm Ansiklopedisi (Ankara: TDV Yayınları, 1993), $8 / 274$.

10 [Çerkeşşeyhizâde], “Tercüme-i Sahib-i Hal-i Divan”, 48.

11 Muhammet Yıldız, Çerkeşizâde Mehmed Tevfik Efendi'nin Kelâmî Görüşleri (Yüksek Lisans Tezi, Karabük Üniversitesi, 2019), 21.

12 Çerkeşşeyhizâde], "Tercüme-i Sahib-i Hal-i Divan”, 49; İbrahim Akyol, "Çerkeşşeyhîzâde Mehmet Tevfik Efendi ve Nefî̀ye Nazîresi”, Çankırı Araştırmaları 1/1 (2006): 178.

13 Çerkeşşeyhizâde], "Tercüme-i Sahib-i Hal-i Divan”, 49; Yıldız, Çerkeşizâde Mehmed Tevfik Efendin'nin Kelâmî Görüşleri, 21.

14 Ylldız, Çerkeşizâde Mehmed Tevfik Efendi'nin Kelâmî Görüşleri, 21-22.

15 Mehmed Tahir, Osmanll Müellifleri, 1/271; Hür Mahmut Yücer, "Bir İbn Arabî Müdafaası: Çerkeşîâade Mehmed Tevfik Efendi ve Levâyihu'l-Kudsiyye fî Fedâili'ş-Şeyhi'l-Ekber Adlı Eseri”, Tasavvuf: İlmîve Akademik Araştırma Dergisi 9/21 (2007), 334.

16 Yücer, "Bir İbn Arabî Müdafaası", 335-337; Ylldız, Çerkeşizâde Mehmed Tevfik Efendinin Kelâmî Görüşleri, 2631. Müellifin akıl risalesi tercüme edilmiştir. Bk. Mehmed Tevfik Efendi, "Akla Dair”, çev. Yasin Apaydın, Osmanl Felsefesi: Seçme Metinler, ed. Ömer Mahir Alper (istanbul: Klasik Yayınları, 2015), 493-503.

17 [Çerkeşşeyhizâde Mehmed] Tevfik Efendi, Risâle fi mahiyeti'l-mümkin ve'l-mec ûliyye (İstanbul: y.y., 1305). 
Son dönem Osmanlı ulemasından Çerkeşşeyhizâde hakkında edebiyat, ${ }^{18}$ tasavvuf, ${ }^{19}$ felsefe $^{20}$ ve kelâm ${ }^{21}$ alanını ilgilendiren konular üzerinden makale, tebliğ ve yüksek lisans düzeyinde bir kısım çalışmalar yapılmıştır. Bu çalışmaların, onun şair kimliğinden yola çıkarak daha çok edebiyat üzerine yoğunlaştı̆̆ı görülmektedir. Onun kelâmî görüşlerinden hareketle yüksek lisans düzeyinde yapılan iki çalışma ise oldukça yakın bir tarihte kaleme alınmıştır (2019). İlgili çalışmalarda tevhîd konusu özel olarak işlenmemiş, sadece onlardan birinde "vacibin taaddüdü" başlığı altında müellifin iki eseri temel alınarak mesele kısa şekilde tetkik edilmiştir. ${ }^{22}$ İş bu makalede ise müellifin tevhîd konusuna bakışı daha geniş bir surette ele alınmış, zikrettiği tüm deliller incelenmiş, diğer eserlerinden de istifade yoluna gidilmiştir. Ayrıca müellifin tevhîd başlığı altında görüşlerine yer verdiği Tabiatçıların ilgili fikirleri ve Allah'a nispet edilen bir çocuğun kadim kabul edilmesi halinde doğacak mahzurlar gibi konuyla bağlantı kurulabilecek bazı meseleler de ilave edilmiştir. Bir mukayese imkânı sunması açısından zaman zaman, kendisiyle çağdaş olan diğer Osmanlı kelâmcılarının meseleye dair açıklamalarına da yer verilmiştir. Müellifin burada tevhîd konusundaki görüşlerine geçmeden önce mevzuyla yakın ilişkisi olan isbât-1 vâcib meselesine bakışını kısaca incelemek uygun olacaktır.

\section{1. Çerkeşşeyhizâde Mehmed Tevfik Efendi'nin İsbât-1 Vâcib Anlayışı}

Kelâmda Allah'ın varlı̆̆ı ve birliği farklı deliller üzerinden ispat edilmeye çalışılsa da bu ikisi arasında bir izaha gerek bırakmayacak şekilde ilişki bulunduğu açıktır. Nitekim Çerkeşşeyhizâde de isbât-1 vâcibin konusu olan varlığı tanımlarken, bu işi yaratıcılık, ma'bûdluk ve vâcibü'l-vücûdluk hususunda bir ve müstakil olan bir varlığı ispat olarak değerlendirmektedir. O, isbât-1 vâcib konusunda kimisi iknaî kimisi kati pek çok delilin

18 i̇brahim Akvol, “Cerkessevhîzâde Mehmet Tevfik Efendi ve Nefî̀ve Nazîresi”. Cankrı Arastirmaları 1/1 (2006). 177-190: Muhittin Eliacık. “Cerkesîzâde Muhammed Tevfik Efendi'nin Vatan Kasidesi”, Çankırı Karatekin Üniversitesi Sosyal Bilimler Enstitüsü Dergisi 2/1 (2011), 51-73; Ali Yörür, "Çerkeşîzâde Mehmed Tevfik Efendi'nin Mi'râciye'si = Mirajiyah of Çerkeşizâde Mehmed Tevfik Efendi", Hikmet Akademik Edebiyat Dergisi = Journal of Academic Literature 4/8 (2018), 229-241; Muhittin Eliaçık, "Halvetiye-Şa'baniye Pîr-i Sânîsi Çerkeşî Mustafa Efendi'nin Torunu Muhammed Tevfik Efendi ve Hediyyetü's-Sıbyan Adlı Eseri = Cherkeshi Mustafa Efendi That Khalvetiye-Shabaniye Second Pir, Grandson Mohammed Tevfik Efendi and His Hediyyetü's-Sibyan", I. Uluslararası Şeyh Şa'bân-ı Velî Sempozyumu -Şeyh Şa'bân-ı Velìyi Anma ve Anlama- (Kastamonu, 4-6 Mayıs 2012) (Kastamonu: Kastamonu Üniversitesi, ts.), 1/179-186; Muhittin Eliaçık, “Çerkeşşeyhizâde Muhammed Tevfik Efendi'nin "Resâil"i=The Booklets of Muhammed Tewfik Efendi”, Çankırı'nın Manevi Mimarları (Çankırı, 2017), haz. İbrahim Akyol vd. (Çankırı: Çankırı Karatekin Üniversitesi Türkiyat Enstitüsü, 2017), 101-104; Fatih Sona, "Çerkeşşeyhi-zâde Muhammed Tevfîk Efendi'nin Nasîhatnâmesi=The Advicebook of Cherkesseyhi-zade Muhammed Tevfik Efendi”, Çankrrinın Manevi Mimarları (Çankırı, 2017), haz. İbrahim Akyol vd. (Çankırı: Çankırı Karatekin Üniversitesi Türkiyat Enstitüsü, 2017), 105-115; Şeyma Yeşil, Çerkeşizaade Mehmet Tevfik Efendi ve Kasâid-i Tevfik'i (Yüksek Lisans Tezi, Ankara Üniversitesi, 2013).

19 Hür Mahmut Yücer, "Bir İbn Arabî Müdafaası: Çerkeşîzâde Mehmed Tevfik Efendi ve Levâyihu'l-Kudsiyye fî Fedâli'ş-Şeyhi'l-Ekber Adlı Eseri”, Tasavvuf: İlmî ve Akademik Araştırma Dergisi 9/21 (2007), 331-351.

20 Yasin Apaydın, “Çerkeşşeyhîzâde Mehmed Tevfik Efendi'nin Mâhiyetin Mec'ûliyeti Meselesine Dair Risalesi: İnceleme ve Tahkik", Tahkik İslami İlimler Araștrma ve Neşir Dergisi = Journal of Critical Edition of Islamic Manuscripts 2/1 (2019), 1-30.

21 Muhammet Yıldız, Çerkeşizâde Mehmed Tevfik Efendi’nin Kelâmî Görüssleri (Yüksek Lisans Tezi, Karabük Üniversitesi, 2019); Aynur Atar, Çerkeşizâade Mehmet Tevfik Efendi ve Akâid Risaleleri (Yüksek Lisans Tezi, Gümüşhane Üniversitesi, 2019).

22 Atar, Çerkeşizâde Mehmet Tevfik Efendi, 67-68. 
kelâm kitaplarında yer aldığını, ancak bu konuda kimsenin kimseyi taklit ile sorumlu olmadığını, hatta bu önemli itikadî meselede herkesin kendi fikri doğrultusunda ispat ile mükellef bulunduğunu söylemektedir. ${ }^{23}$

Meziyyet-i İslamiyye adlı eserinde bu konuda iki deli getireceğini ifade eden müellif, önce bazı mukaddimelere yer verir. İlk olarak bir fiil veya eserin fail veya müessir olmadan gerçekleşemeyeceğini belirtir. Buna göre failsiz fiilin vukuu muhaldir. Bu kaide öylesine açıktır ki, temyiz çă̆ına erişmemiş bir çocuk dahi onun bilgisine sahiptir. İnsan bu yönde fitri bir bilgiyle donatılmıştı. îkinci olarak bir şeyin varlığııı illeti kendindenönce olmak durumundadır. Üçüncü olarak vacib, mümkün ve mümteni kavramları hakkında bilgi veren müellif, ilkinin varlığının zatı gereği olup, onun başka bir şeye muhtaç olmadan var olduğunu söyler. İkincisinin ise zatına nispetle varlığı ve yokluğunun eşit olduğunu, zatının ne varlığını ne de yokluğunu gerektirdiğini, her iki durum için de müessir bir güce ihtiyaç duyduğunu ifade eder. Mümteninin ise zatı, yokluğunu gerektiren ve varlık ile nitelenmesi mümkün olmayan durum için kullanıldığını belirtir. Sonuç olarak varlı̆̆ın ilk iki madde için söz konusu edilebileceğine dikkat çeker. ${ }^{24}$

Diğer bir eserinde mezkûr üç kavrama dair ilave açıllamalarda bulunur. Buna göre vacib (zorunlu varlık), aynı zamanda başlangıcı ve sonu olmayan varlıktır. Bu durum Allah ve sıfatları için geçerlidir. Mümkün varlık ise hem felekler, unsurlar, hayvanlar, bitkiler, madenler, cevher ve arazların içine dâhil olduğu, başlangııı ve sonu bulunan varlıklar; hem de ahiret ve orada bulunan diğer şeylerin varlığında olduğu üzere başlangıcı olup sonu olmayan mevcutlar için kullanılır. ${ }^{25}$ Mümkün, aklın açıkça gösterdiği üzere kendi başına var olamaz, bunun için mutlaka kendisine varlık kazandıracak bir var ediciye ihtiyaç duyar. ${ }^{26}$ Mümkünün varlık kazanmak için bir faile ihtiyaç duyduğu hususunda bütün fikirler birleşir. Zaten aksi bir durumda o mümkün değil, ${ }^{27}$ zorunlu varlı olmuş olur. ${ }^{28}$ Mümteni ise, bir sayının hem çift hem de tek olması örneğinde görüldüğü üzere varlığını farzetmenin muhal bir duruma sebebiyet verdiği şeydir. ${ }^{29}$

Üç mukaddimeyi bu şekilde aktaran müellif dördüncü mukaddimeyi de izah etmeye başlar. Buna göre mümkün kendi zatını var edemez. Eğer zatına varlık kazandırırsa iki durum söz konusu olur. Ya varlık ve yokluk kendisi açısından eşit iken zatını var etmiş olabilir. Ya da zatı, varlı̆̆ını gerektirmesi suretiyle varlık kazanmış olabilir. Hâlbuki her iki şı da muhaldir. Zira ilk durumda tercih bilâ müreccih (Hiçbir üstünlük sebebi yok iken birbirine eşit iki şeyden birisini diğerine üstün tutmak) gerçekleşir. İkincisinde ise onun vacip bir varlık olması gerekir. Bu ise farzedilenin aksi bir duruma sebebiyet verdiği için doğru

${ }^{23}$ Çerkeşşeyhizâde Mehmed Tevfik Efendi, Meziyyet-i İslamiyye (Dersaâdet: Mahmud Bey Matbaası, 1307), 8.

24 Çerkeşşeyhizâde, Meziyyet-i İslamiyye, 8.

25 Çerkeşşeyhizâde Mehmed Tevfik Efendi, Miftâhu'l-akâid (isstanbul: Mihran Matbaası, 1301), 9.

${ }^{26}$ Çerkeşşeyhizâde Mehmed Tevfik Efendi, el-ittkân fî tahkîki'l-îmân (İstanbul: Âlem Matbaası, 1311), 57.

${ }^{27}$ [Çerkeşşeyhizâde Mehmed] Tevfik Efendi, Risâle fi mahiyeti'l-mümkin ve'l-mec ûliyye (istanbul: y.y., 1305), 1.

${ }^{28}$ Yasin Apaydın, “Çerkeşşeyhîzâde Mehmed Tevfik Efendi'nin Mâhiyetin Mec'ûliyeti Meselesine Dair Risalesi: İnceleme ve Tahkik", Tahkik İslami ilimler Araştırma ve Neşir Dergisi = Journal of Critical Edition of Islamic Manuscripts 2/1 (2019), 6.

${ }^{29}$ Çerkeşşeyhizâde, Miftâhu'l-akâid, 9. 
değildir. Sonuçta her iki seçenek de batıl olunca mümkünün kendi varlığını ortaya çıarması devre dışı kalır. Kendi zatını var edemeyen böyle bir mümkün varlığın başka bir şeye varlık kazandıramaması da olağandır. ${ }^{30}$

Müellif isbât-1 vâcib için gerekli gördüğü mukaddimeleri bu şekilde aktardıktan sonra artık onları doğrudan Allah'ın varlığını kanıtlamak ile bağlantılı hale getirir. Buna göre birinci ve ikinci mukaddimeler, bir şeyin var olmak için mevcut bir faile ihtiyaç duyduğunu göstermektedir. Üçüncü mukaddime, mevcudun iki şeyle (vacib-mümkün) sınırlandığını; dördüncü mukaddime ise mümkünün kendi zatına veya başka bir varlığa illet olamayacağını ortaya koymaktadır. Bu durumda çeşitli değişim ve teşekküller ile imkân ve hâdisliği ortaya çıkan mevcut âlemin fail illetinin, akli olarak bu imkân silsilesinin d1şında bulunan bir vacip varlık olması gerekir. Müellif, ilgili mukaddimeler üzerinden delili bu şekilde ortaya koyduktan sonra onların yakîne dayalı olduğundan hareketle bu kanıtın burhan tarzında olduğunun da altını çizer. ${ }^{31}$

Müellif ilgili isbât-1 vâcib delilinin aslında yeterli bir güce sahip olsa da konunun önemine binaen bir kanıt daha zikretmek istediğini beyan eder ve bu delilin izahına başlar. Burada da bir önceki delilde kullandığı mukaddimelere atıflar yapar. Buna göre dördüncü mukaddimenin gösterdiği üzere mümkünün ne kendi zatına ne de başka bir varlığa illet olması söz konusu değildir. Bu aşamada Vâcibü'l-vücûd'un (zorunlu varlığın) yokluğu farz edilirse, varlığın sadece mümkün ile sınırlanması gerekir. Bu ise mevcut mümkünlerin, ya illetsiz bir şekilde varlık kazanmasını ya da bu mümkünlerin var etme hususunda illet olmasını gerektirir. Her iki durum da birinci ve dördüncü mukaddime gereği muhaldir. 0 halde bu muhale sebebiyet veren zorunlu varlığın yokluğu da muhaldir. Bu durumda Vâcibü'l-vücûd'un varlığı sabit olmuş olur. ${ }^{32}$

Müellif, ikinci delili akli yoldan bu şekilde ortaya koyduktan sonra çıan neticeyi teyit eder mahiyette bir kısım âyetlere de yer verir. Bu bağlamda Allah'ın kendisinden başka ilah olmadığına şahitlik ettiği ${ }^{33}$ göklerin ve yerin yaratılışında, gece ile gündüzün birbirini takip etmesinde, gemilerde, yağmurda, canlıların yayılmasında, rüzgâr ve bulutlarda akıl sahipleri için ibretler bulunduğu, ${ }^{34}$ ufuklarda ve nefislerde O'nun kudret işaretlerini göstereceği $;^{35}$ insanın bayağı bir sudan yaratıldığ ${ }^{36}$ ve yerin, göğün yaratılışının, dillerin ve renklerin farklı oluşunun O'nun âyetlerinden olduğ $\mathrm{u}^{37}$ mealindeki ilahi kelâm örneklerini aktarır. Hemen ardından varlığı bu şekilde ispat olunan o ilahın, hayat, ilim, irade gibi sıfatlarla mücehhez olması gerektiğine işaret eder. Bunu da hakikatini ve niceliğini aklın

30 Çerkeşşeyhizâde, Meziyyet-i İslamiyye, 8-9. Bu meselelerin izahında kelamclara ilham olan İbn-i Sînânın imkân, vacib ve mümteni kavramları hakkında getirdiği açıklamalar için bk. Ebû Alî Hüseyn b. Abdillâh b. Alî b. Sînâ İbn Sinâ, el-Işsarat ve't-tenbihat, thk. Süleyman Dünyâ (Kahire: Dâru'l-Maârif, 3. Basım, ts.), 272-276.

31 Çerkeşşeyhizâde, Meziyyet-i İslamiyye, 9. Müellif, bir diğer eserinde ortaya çıkan bu duruma mebni olarak âlemin de hâdis olması ve bir örneği daha önce gerçekleşmemiş şekilde yoktan var edilmesi gerektiğine dikkat çeker. Bk. Çerkeşşeyhizâde, Miftâhu'l-akâid, 10.

32 Çerkeşşeyhizâde, Meziyyet-i İslamiyye, 9.

33 Âl-i İmrân 3/18.

34 el-Bakara 2/164.

35 Fussilet 41/53.

36 Mürselât 77/20.

37 er-Rûm 30/22. 
idrakten aciz kaldığı evrendeki müthiş düzen ve sağlam fiillerin ilgili kemal sıfatları gerektirmesi üzerinden açılar. ${ }^{38}$

\section{2. Çerkeşşeyhizâde Mehmed Tevfik Efendi'nin Tevhîd Düşüncesi}

Çerkeşşeyhizâde marifetullah ve isbât-1 vâcib gibi ulûhiyetin temel meseleleri d1şında tevhîd konusunu da inceler. $O$, farklı eserlerinde muhtelif başlıklar altında bu meseleyle ilgili olarak tevhîdin mahiyeti, sıfat-zat ilişkisi noktasında tevhîdin korunması, İslam filozoflarının sudur teorisinin tevhîd bağlamında değerlendirilmesi, tevhîde aklen ulaşmanın imkânı ve tevhîd delilleri üzerinde durur. Bu meselede mesaisini daha çok ilgili deliller üzerine harcar. Tevhîd ile ilgili diğer konularda ise oldukça kısa izahlar getirir. Bunlardan birinde tevhîdden ne anlaşılması gerektiği hakkındaki fikrini belirtir. Buna göre tevhîd Cenâb-1 Hakk'ın vâcibü'l-vücûd, yaratıcı ve ma'bud olma hususunda bir olması demektir. Bu üç niteliği ona tahsis etmeden tevhîdin gerçekleşmesi mümkün değildir. ${ }^{39}$ Müellif, bir diğer eserinde Allah'ın varlığına imandan sonra bir müminin inanması gereken hususları sayarken yer verdiği tevhîd maddesinde de onun unsurlarını yine bu üç sıfat üzerinden ortaya koyar. ${ }^{40}$ Bunların ilki, Cenâb-1 Hakk'ın zatı; ikincisi ise fiilleri itibariyle bir olmasını simgelemektedir. Ma'bud olma yönündeki tevhîdi ise ulûhiyet yani ibadete layık olma hususundaki birliğini göstermektedir. ${ }^{41}$ Onun bu ma'budiyetteki birliği aynı zamanda tevhîd-i irâdî şeklinde de anılmaktadır. ${ }^{42}$

Müellifin çağdaşlarından olan Abdüllatif Harpûtî (1842-1916) de bu birliği, Allah'ın vâcibü'l-vücûd oluşu, yaratıcllı̆̆ ve ulûhiyeti hususunda bir ortağının olmaması ile izah eder. Böylece her iki kelâmcı da aynı noktada buluşmuş olur. ${ }^{43}$ Bununla birlikte Allah'ın birliğini O'nun zatı, sıfatları ve filleri üzerinden izah eden Arapgirli Hüseyin Avni (öl. 1954), ${ }^{44}$ Süleyman Sırrı (1851-1931) ${ }^{45}$ Hafız Kamil Efendi ${ }^{46}$ ve Hac1 Necib; ${ }^{47}$ onlara isimlerinde birliğini ilave eden Mustafa Asım ${ }^{48}$ ile Mehmed Emin Eskişehrî ${ }^{49}$ ve bu dört maddeye O’nun kaza ve hükmünü ekleyen Manastırlı İsmail Hakkı (1846-1912) ve Mehmed Haşimº

38 Çerkeşşeyhizâde, Meziyyet-i İslamiyye, 9-10.

39 Çerkeşşeyhizâde, Meziyyet-i İslamiyye, 8; Çerkeşşeyhizâde Mehmed Tevfik Efendi, Risâle fi hakki fâkidi'ssalât (İstanbul: Mahmut Bey Matbaası, 1308), 204.

40 Çerkeşşeyhizâde, el-ìtkân fi tahkîki'l-îmân, 27.

41 İzmirli İsmail Hakkı, Mülehhas İlm-i Tevhîd (İstanbul: Kanaat Matbaası, 1338), 102; Ömer Nasuhi [Bilmen], Muvazzah İlm-i Kelâm Dersleri (İstanbul: Evkâf-1 İslâmiyye Matbaas1, 1339-1342), 152; Mehmet Kubat, Kur'ân'da Tevhîd (İstanbul: Beka Yayınları, 2014), 175.

42 İzmirli İsmail Hakkı, Mülehhas İlm-i Tevhîd, 102; M. Şemseddin [Günaltay], Felsefe-i Ûlâ: İsbât-ı Vâcib ve Ruh Nazariyeleri (Şehzadebaşı: Evkâf-1 İslâmiyye Matbaası, 1339-1341), 118.

43 Abdüllatif Harpûtî, Tenkîhu'l-Kelâm fî Akâid-i Ehli'l-İslâm (Dersaâdet: Necm-i İstikbal Matbaası, 1330), 181.

44 [Arapkirli] Hüseyin Avni, “İlm-i Kelâm”, Dârülfünûn Dersleri (İstanbul: İstanbul Dârülfünunu, 1331), 4.

45 Süleyman Sırrı, Kenzü'l-akâid (Dersaâdet: Ahter Matbaası, 1316), 45; Süleyman Sırrı, Miftâhu'l-akâid (İstanbul: Mahmud Bey Matbaası, 1321), 27.

${ }^{46}$ Hafiz Kamil, Cevahirül-kelâm fî beyâni akaidi'l-İslam (Kastamonu: Matbaa-i Vilayet, 1334), 13. Hafiz Kamil ayrıca tevhîde O'nun ma'budiyetinde birliğini de ilave eder. Bk. Hafiz Kamil, Cevahirül-kelâm, 13.

47 Hacı Necib, Kenzül-feraid fi mesaili'l-akaid (Dersaadet: Kanaat Matbaası, 1335), 22.

48 Mustafa Asım, Akaid Dersleri (Dersaâdet: Hilal Matbaası, 1324), 12-13.

49 Mehmed Emin Eskişehrî, Zübdetü'l-akâid (İstanbul: Süleyman Efendi Matbaas1, 1298), 16.

50 Mehmed Haşim, Zübde-i akaid-i İslamiyye (İstanbul: Bâbıâli Caddesi 13 Numaralı Matbaa, 1319), 56. 
gibi son dönem Osmanlı ilim adamları da vardır. ${ }^{51}$ Tabi bu durum, onların tevhîdi farklı algıladıklarını değil, onu başka bir yönden izah ettiklerini gösterir. Nitekim Manastırlı bir diğer eserinde tevhîdi; Allah'ın zat, sıfat ve fiilleri üzerinden ortaya koymakta, ${ }^{52}$ bir diğer Osmanlı kelâmcısı Ömer Nasûhî (1883-1971) ise bunlara ulûhiyet-ma'budiyette birliğini ilave etmekte, ${ }^{53}$ İzmirli İsmail Hakkı ise (1869-1946) ayrıca ilgili maddelere rubûbiyette birliğini eklemektedir. ${ }^{54}$

Çerkeşşeyhizâde, ilahi sıfatlar konusunu ele alırken de tevhîde dair bir açılama yapar. Meselenin henüz ilk aşamasında onların varlığını kabulün tevhîde aykırı olmayacağını belirtir. Buna göre Allah'ın, zatıyla kaim, ancak zatından farklı ve O'ndan ayrılması asla mümkün olmayan sekiz ezeli sıfatı bulunmaktadır. Bu sıfatların taaddüdü, kesinlikle Zat'ının birliği düşüncesine aykırı değildir. ${ }^{55}$ Böylece müellif, Mu'tezile'nin tevhîde aykırı olduğu düşüncesiyle mana sıfatlarını kabul etmeyen yaklaşımını reddetmiş, Ehl-i sünnetin anlayışını ilgili izah biçimiyle benimsediğini göstermiş olur.

Müellif, âlemin hudûsü başlığı altında İslam filozoflarının sudur teorisini ele alırken de konuyu bir yönüyle tevhitle bağlantılı bir hale getirir. İlgili yaklaşımı kısaca izah ettikten sonra Pythagoras (öl. MÖ. 504) ve Sokrat (öl. MÖ. 399) gibi filozofların cisimlerin zatları itibariyle kadimliğine, sıfatları itibariyle hâdisliğine hükmettiklerini belirtir. Buna karşıllk Aristo (öl. MÖ. 322), Fârâbî (öl. 339/950) ve İbn Sînâ (öl. 428/1037) gibi filozofların ise cisimleri hem zat hem de sıfatları itibariyle kadim gördüklerine dikkat çeker. Sonuç olarak her iki yaklaşımın da kadim varlıkların çokluğu anlayışını gerektirmesi ve Allah'ı zorunlu bir fail konumuna getirmesi nedeniyle küfür olduğuna işaret eder. ${ }^{56} \mathrm{Bu}$ konuda Ehl-i sünnetin savunduğu üzere âlemin hâdis olduğunu, yani yok iken sonradan bütün cüzleriyle varlık kazandığını belirtir. ${ }^{57}$ Müellifin burada ilgili sudur görüşünü küfür olarak değerlendirirken, bunu tevhîde aykırılık üzerinden gerekçelendirmesi dikkat çekicidir. Benzer bir yaklaşımı Harpûtî'de de görmek mümkündür. O, tevhîd konusunu işlerken görüşlerine yer verdiği filozofların "birden bir sudur eder" şeklindeki anlayışlarından hareketle bir öncekinin kendisinden sonrakini var edecek surette onlu akıl sistemi üzerinden geliştirdikleri düşünce ile yaratıcılık ve vahdaniyet konusunda İslam'ın temel yaklaşımına aykırı düştüklerini belirtir. ${ }^{58}$ Yine Süleyman Sırrı da Allah'ın ortağının olmadığını açıladığı bir bölümde filozofların ileri sürdükleri sudur teorisinin akli ve nakli delillere aykırı olup, onun yanlışlığını izaha gerek bile bulunmadığını belirtir. ${ }^{59}$

Çerkeşşeyhizâde, sudur teorisinden bahsettiği sırada feleklerin ne olduğuna dair çeşitli fikirleri aktardıktan sonra da Allah'ın ilk yarattığı şeyin Hz. Muhammed'in nuru olduğunu ifade eder. Hemen ardından onun kadim ve ezeli olmadığını vurgulayarak, kadim

51 Manastırlı İsmail Hakkı, Mevaidül'-in'am fi berâhîni akaidil-İslâm (İstanbul: Şirket-i Sahafiye-i Osmaniye Matbaas1, ts.), 45.

52 Manastırlı İsmail Hakkı, Telhîsü'l-kelâm fî berâhîni akâidi'l-İslâm (İstanbul: Sırat-1 Müstakim Matbaası, 2. Basim, 1329), 40.

53 Ömer Nasuhi, Muvazzah İlm-i Kelâm, 151.

54 İzmirli İsmail Hakkı, Mülehhas İlm-i Tevhîd, 102.

55 Çerkeşşeyhizâde, Miftâhu'l-akâid, 10-11. Müellif bir diğer eserinde yine bu subuti sıfatların Zat'ın ne aynı ne de gayrı olduğu ifadelerini tekrarlar. Bk. Çerkeşşeyhizâde, el-ítkân fi tahkîki'l-îmân, 27.

56 Çerkeşşeyhizâde, Meziyyet-i İslamiyye, 3.

57 Çerkeşşeyhizâde Mehmed Tevfik Efendi, Hudûsü'l-âlem, Atıf Efendi Kütüphanesi, nr. 4657, 43b-44a.

58 Harpûtî, Tenkîhu'l-Kelâm, 184.

59 Süleyman Sirrı, Kenzü'l-akâid, 65. 
varlıkların çokluğu görüşüne düştüklerini söylediği filozofların anlayışından kendisini uzak tutmaya çalışır. Bu manada zikredilen nurun zamansal olarak da hâdis olduğuna dikkat çeker. ${ }^{60}$ Böylece söz konusu nurun, filozofların zaman itibarıyla kadim olduğunu söyledikleri âlem gibi bir konumu olmadığını, dolayısıyla onlarla aynı hataya düşmediğini vurgulamış olur.

Musannıf bu konuda aklın tevhîdi bulma hususundaki yeterliliğine dair de görüş bildirir. O, aklın Allah'ın birliğini tıpkı O'nun varlığı gibi müstakil olarak bulabileceğini ileri sürer. Âlemi ibret nazarıyla inceleyen kişinin onun birlik şanından olan bir varlık tarafından yaratıldığını tasdik edeceğini belirtir. Bu manada kendisine nebi ulaşmayan akıllı ve ergin bir kimsenin Allah'ın varlık ve birliğini tasdik etmezse, ebedi cehennemde kalacağını savunur. Hem geliştirdiği izah tarzından hem de bu konuda Nûreddin esSâbûnî̀ye (öl. 580/1184) atıf yapmasından müellifin bu meselede Mâtürîdî çizgiyi takip ettiği anlaşılmaktadır. ${ }^{61}$ Bir diğer eserinde nazar ehlinin kim olduğunu izah ederken, onun yerin, göğün yaratılışını, gece, gündüzün oluşumunu ve kendi nefsini tefekkür ederek Allah'ın varlığı ve bir liğine ulaşan kişi olarak tanımladığı görülür. ${ }^{62}$ Böylece yine Allah'ın varlık ve birliğini bilme ya da bulma noktasında bu ikisi arasında fark görmediğini ortaya koymuş olur.

Çerkeşşeyhizâde bu konu etrafındaki izahlarını ağırlıklı olarak tevhîd delilleri üzerine yoğunlaştırır. Bu manada nakli ve akli bir kısım delillerden istifade ile tevhîd anlayışını ortaya koyar ve itikadî alana hasrettiği veya bu sahayla ilgili meselelere yer verdiği bazı eserlerinde mevzuya temas eder. Bu manada itikadî meselelerden özel olarak bahsettiği Meziyyetü'l-islâm ve Miftâhu'l-akâid adlı eserlerinde belli başlı tevhîd delillerine yer verdiği gibi, tevhîd konusunda kaleme aldığı bir kasidesinde de ilgili delillerin önemli bazı noktalarına atıflarda bulunur.

\subsection{Tevhîd Delilleri}

Tevhîd bahsini, İslam inancının en büyük meselelerinden biri olarak niteleyen müellif, bu konuda muhtelif delillere başvurur. Bu delilleri aktarırken kimi zaman onun adını zikretme yolunu seçerken bazen de böyle bir yola başvurmadan doğrudan ilgili kanıtı aktarır. Diğer pek çok mevzuda yaptığı gibi bu meselede de önce giriş mahiyetinde birtakım açılamalar yapar. Sonrasında ilgili delili o mukaddime veya izahlar üzerine bina eder. Böylece konunun daha iyi anlaşılmasının önünü açar. Onun tevhîd babında zikrettiği delillerin ilki, vâcibü'l-vücûd kavramının gerektirdiği "bir olma” manası üzerine bina edilir. Şüphesiz bu konuda daha çok temânu' (irade çatışması) delili üzerinde durur. Bununla birlikte başka bir takım delillere daha yer verir.

\subsubsection{Vâcibü'l-Vücûd Oluşundan Hareketle İlahın Birliği}

Müellif, ilgili delili aktarmadan önce bazı izahlarda bulunur. İlk aşamada klasik kelâm kitaplarında çok da örneğine rastlanmayan bir şekilde "Allah, kuluna yetmez mi?"*3

60 Çerkeşşeyhizâde, Meziyyet-i İslamiyye, 4-5.

61 Çerkeşşeyhizâde, Meziyyet-i İslamiyye, 6-7.

62 Çerkeşşeyhizâde, el-ìtkân fi tahkîki'l-îmân, 20.

63 ez-Zümer 39/36. 
âyeti ile meseleye başlar. Bu ilahi kelâmı, âlemde müessir olan zorunlu bir varlığın yeterliliğini ortaya koyan ve O’nun gibi başka bir varlığa ihtiyaç bırakmayan bir ifade olarak yorumlar. Ardından ilgili manaya bağlı olarak vâcibü'l-vücûd/zorunlu varlık kavramı üzerine bina edilen bir izah geliştirir. ${ }^{64}$

Buna göre zorunlu varlı̆̆ın bir şeriki/ortağı farzedilse, onun da zorunlu olması gerekir. Zira mümkün bir varlığın zorunlu varlığa ortak olması söz konusu değildir. Ancak bu ikinci farazi varlığın zorunlu bir varlık olması da mümkün değildir. Çünkü isbât-1 vâcib delillerinin gösterdiği üzere, böyle bir zorunlu varlığın yokluğunu düşünmek muhal iken, ona ortak olarak tasavvur edilen varlığın yokluğunu farz etmek hiçbir muhallik içermez. Böylece varlığı vacip yani zorunlu varlığın ortağı, imkân dairesi içerisine girmemiş olur. ${ }^{65}$

Müellif, bu açıklamaları takiben onu isbât-1 vâcib ve tevhitle bağlantılı hale de getirir. Buna göre âlemi varlığa çıkaran, vücudu zorunlu etkin bir fail olmasa, bu gözlemlenen kâinatın var olmaması gerekir. Hâlbuki duyularla müşahede edilen âlemin varlığının gösterdiği üzere bu ihtimal söz konusu değildir. İște bu durumdan âlemi var eden zorunlu bir varlığın vücudu gerektiği gibi, O'nun bir ve tek olması da gerekir. Zira belirtildiği üzere, O'na ortak bir varlığın yokluğunu düşünmek hiçbir şekilde bir fesada sebebiyet vermemektedir. Bundan da o farazi ortağın vacip değil, mümkün varlık olduğu ortaya çıkar. Böyle mümkün bir varlığın da vacip varlığa, fiillerinde eşlik etmesi ihtimal dâhilinde değildir. Bu da, varlığı zorunlu olan Allah'ın âlemde etkin olduğunu ve ezelden ebede tek başına bu hükümranlığını hiçbir engelle karşılaşmadan sürdürdüğünü ve sürdüreceğini gösterir ${ }^{66}$ Yine ilgili akaid risalesinde Mehmed Haşim'in de vâcibu'l-vücûd kavramının sadece bir varlık için kullanılabilmesinden hareketle Allah'ın bir olduğu yönünde çıkarımda bulunduğu görülür. ${ }^{67}$ Benzer bir bilgi aktaran Hüseyin Avni de aksi bir düşüncenin aklen imkânsız olduğuna dikkat çeker. ${ }^{68}$ Yine bir akaid risalesi kaleme alan Mustafa Asım da vâcibü'l-vücûd olanın doğal olarak zatında bir olacağına işaret ile aynı hususa vurgu yapar. ${ }^{69}$ Böylece her üç kelâmcı da ilgili yaklaşımı sürdürmüş olurlar.

\subsubsection{Temânu' Delili}

Müellif, kelâmcıların tevhîd konusunda "Eğer yerde ve gökte Allah'tan başka ilahlar bulunsaydı kesinlikle yerin göğün düzeni bozulurdu."70 âyetinden hareketle ortaya koydukları temânu' deliline de yer verir. Önce kâmil bir irade ve kudrete sahip olan Allah'ın birden fazla olma imkânının muhaliyetine dair ön kabulünü zikreder. Ardından bu görüşünü ispatlamaya çalışır. Ona göre vacip varlığın birden fazla olabileceğine dönük kabul edilen imkân, onların arasındaki ihtilaf imkânını da beraberinde getirir. Bu çatışma imkânı ise pek çok fesadı gerektirmesi nedeniyle muhal olduğundan bu durum vacip varlığın çokluğu seçeneğini de muhal hale getirir. Örneğin onlardan biri bir kişinin hareketini, diğeri sükûnunu murat ettiğinde bazı durumlar gündeme gelir. Burada ya ikisinin de dileği gerçekleşir. Bu aşamada bir şahsın aynı anda iki zıt sıfat ile nitelendirilmesini kabul gerekir.

\footnotetext{
64 Çerkeşşeyhizâde, Meziyyet-i İslamiyye, 10.

65 Çerkeşşeyhizâde, Meziyyet-i İslamiyye, 10.

66 Çerkeşşeyhizâde, Meziyyet-i İslamiyye, 11.

67 Mehmed Haşim, Zübde-i akaid-i İslamiyye, 57.

68 Hüseyin Avni, "İlm-i Kelâm”, 4.

69 Mustafa Asım, Akaid Dersleri, 12.

70 el-Enbiyâ 21/22.
} 
Şayet bunlardan birinin muradı gerçekleşmezse, onun acziyeti ortaya çlkar. İște her iki ihtimal de batıl olunca, vacip varlığın birden fazla olma imkânı devre dışı kalır. Böylece ilgili zorunlu varlığın tek olduğu ortaya çıkar. ${ }^{71}$

Temânu' deliline yer veren Harpûtî de, biri bir şeyin varlı̆̆ını diğeri yokluğunu dileyen iki ilah tasavvuruna bağlı olarak meseleyi üç ihtimal üzerinden aktarır. Önce bu seçeneklerin her birinin muhal olduğuna dair hükmünü belirtir. Sonrasında gerekçelerini zikreder. Buna göre ikisinin de dileklerinin gerçekleşmesi halinde iki zıddın bir şeyde toplanması (ictimâ-i nakizeyn), isteklerinin olmaması durumunda iki zıddın ortadan kalkması (irtifâ-ı nakizeyn) ve onların acizliği, nihayet birinin dediğinin olması aşamasında ise diğerinin acziyeti ortaya çıkar. Bütün bu ihtimaller mümkün olmadığından birden fazla ilahın varlığı imkânsız olur. Dolayısıyla ilah tektir. ${ }^{72}$ Bir akaid risalesi kaleme alan İbrahim Natıkî de bu delili aynı surette nakleder. ${ }^{73}$ Hüseyin Avni ile Ömer Nasûhî ise onu, ikinci seçenekte sadece iki zıddın vuku bulmaması üzerinden izahla yetinmek dışında Harpûtî gibi aktarırlar. ${ }^{74}$ Manastırlı İsmail Hakkı, Mehmed Haşim ve Şemseddin Günaltay ise (1883-1961) temânu delilini iki ilahın irade çatışmasından ortaya çıkacak iki zıddın içtimal ve acizlik ihtimallerine atıfta bulunarak anlatırlar. ${ }^{75}$ Mehmed Vehbi Efendi de (1862-1949) bu delili Manastırlı İsmail Hakkı gibi açıklar. ${ }^{76}$ Bu durumda Çerkeşşeyhizâde'nin temânu' delilini aktarırken ilahların acizliği ve içtima-ı zıddeynin batıl olması seçeneklerini kullanırken, irtifâ-ı nakîzeynin imkânsızlı̆̆ı bağlamında bir izah geliştirmediği anlaşılmaktadır.

Öte yandan Çerkeşşeyhizâde ilgili âyet üzerinden temânu' delilinin kesinlik bildirip bildirmediği hususunda da görüş beyan eder. Öncelikle burada söz konusu âyetin lafız ve sigasından ilk aşamada anlaşlan ve lafzın ilk veya ikinci planda sevkediliş gayesini bildiren "dâll bi'l-ibâre" şeklindeki ibare delaleti ile "lafzın, ibarenin delaletinin ve sözün sevkediliş gayesinin dışında kalan, fakat yine de dil ve mantık kurallarına göre lafızdan dolaylı olarak çıkarlabilen bir manaya delalet"” bildiren "dâll bi'l-işare" şeklindeki işaret delaleti arasında ayrım yapar. İzahlarını âyetin bu iki delaletine göre şekillendirir. Buna göre âyet, ibare delaletiyle iknaî bir mahiyet arzederken; ortaya konulan temânu' delilindeki manaya işaret etmesi, yani işaret delaleti itibariyle yakîn/kesinlik bildirmektedir. ${ }^{78}$ Mehmed Vehbi Efendi ise bu tür bir ayrıma gitmeden delilin iknâi mahiyette olduğunu belirtir. Bunu da hâkim konumunda olan birden fazla gücün âdeten bir çatışma içerisine girecek olmass ile izah eder. ${ }^{79}$

Çerkeşşeyhizâde ilk planda böyle bir açıllama yapmakla birlikte hemen ardından aslında âyetteki ilahtan, müessir bir yaratıcı; fesattan da âlemin oluşmaması manası murat

\footnotetext{
71 Çerkeşşeyhizâde, Meziyyet-i İslamiyye, 11.

72 Harpûtî, Tenkîhu'l-Kelâm, 181-182.

73 İbrahim Natıkî, Risale-i akäidül-İ́slam (Dersaâdet: Matbaa-i Osmaniye, 1300), 18-19.

74 Hüseyin Avni, "İlm-i Kelâm”, 6; Ömer Nasuhi, Muvazzah İlm-i Kelâm, 155.

75 Manastırlı İsmail Hakkı, Mevaidü'l-in'am, 48-50; Mehmed Haşim, Zübde-i akaid-i İslamiyye, 58; M. Şemseddin [Günaltay], Felsefe-i Ûlâ, 117.

76 Mehmed Vehbi, Akâid-i Hayriye Tercümesi (İstanbul: Ahmed Kamil Matbaas1, 1340-1343), 23.

77 Ali Bardakoğlu, "Delâlet”, Türkiye Diyanet Vakfi İslâm Ansiklopedisi (Ankara: TDV Yayınları, 1994), 9/121.

78 Çerkeşşeyhizâde, Meziyyet-i İslamiyye, 11.

79 Mehmed Vehbi, Akâid-i Hayriye Tercümesi, 31.
} 
olduğunda, bu ilahi kelâmın ibare delaletiyle de yakîn bildirdiğini ve buna bağlı olarak durumun kesinlik arzettiğini kaydeder. Ardından verdiği bu hükmün gerekçesini sunar. Buna göre yerde ve gökte birden fazla ilahın varlığı mümkün olsa, bu iki ilah, varlık ve varlıklarının zorunluluğu hususunda "müşterek"; birbirlerinden ayrıldıkları yön itibariyle farklı (mütemâyiz) olmaları gerekir. Bu ise, o iki ilahın her birinin ayrı ayrı söz konusu müşterek ve mütemâyiz yönlerden terkibini, yani mürekkeb olmasını gerektirir. Mürekkeb varlık ise mümkün bir varlık olup yaratma gücünden uzak olduğundan yer ve gökte böylesi iki müessir ilah olsa, bu âlemin mevcut olmaması gerekir. Hâlbuki âlemin varlığı ortada iken onun yokluğu iddiasının yanlışlı̆̆ı aşikârdır. Bu durumda yerde ve gökte müessir ilahın çokluğu seçeneği batıl olur. Buna bağlı olarak da Cenâb-1 Hakk’ın birliği kesin bir şekilde sabit olmuş olur. ${ }^{80}$

Müellifin, temânu' deliline değindiği bir başka eseri, Sırrı Girîdî̉nin (1844-1895) Sa'düddîn et-Teftazânînin (öl. 792/1390) Şerhu'l-akaid'ini tercüme ettikten sonra ondan bazı kısaltmalar ve alıntılar yaparak yarı tercüme yarı telif tarzında oluşturduğu Nakdü'lkelâm'dır. ${ }^{81}$ Burada Sırrı Paşa'nın ilgili âyetteki (el-Enbiyâ 21/22) fesadı, iki ilahın bulunması halinde âlemin oluşmayacağı üzerinden izah ettiğini belirtir. Onun bu noktada yaptı̆̆ı takririn eksikliğini vurgular. Gerçekten de Sırrı Paşa, tevhîd delili olarak yer verdiği temânu delilini izah ederken "Allah Teâlâ'dan gayrı sıfat-1 ulûhiyeti câmî iki ilah olsa, arz u sema ve sâir eşyâ mevcud olmamak lazım gelirdi” şeklinde bir ifade kullanmaktadır. ${ }^{82}$ Hâlbuki Çerkeşşeyhizâde ilgili âyette söz konusu edilen açmazın âlemin oluşmayacağı değil orada düzenin bozulacağı hususunda ortaya konulduğunu düşünür. Yine ona göre Sırrı Paşa'nın ilgili ifadesinden Allah'tan başka ulûhiyet sıfatlarına sahip bir ilah olsa herhangi bir bozukluk olmayacağı gibi bir anlam da doğmaktadır. Bu durumun yanlışlığı açık oldugundan ilgili ifade her halükarda yanlıştır. ${ }^{83}$

Öte yandan Çerkeşşeyhizâde, temânu' delilinin âlemin varlık alanına çıkamayacağı üzerinden izah edilmesine karşı çıkıp bu yaklaşımı eleştirse de aynı izah tarzının Manastırlı İsmail Hakkı gibi diğer bir son dönem Osmanlı kelâmcısı tarafından da ortaya konulduğu görülmektedir. ${ }^{84}$ İlgili âyetin bağlamına bakıldığında Çerkeșşeyhizâde'nin bu konuda haklı bir eleştiri getirdiği anlaşılmaktadır. Nitekim Sırrı Paşa, muhtemelen onun bu tenkitlerini de göz önüne alarak, adı geçen eserinin sonraki baskısında bir tashihe gitmiş ve "arz u semâ ve sâir eşyâ mevcud olmamak lazım gelirdi” şeklindeki ifadesini metinden çıkarmıştır. ${ }^{85}$

80 Çerkeşşeyhizâde, Meziyyet-i İslamiyye, 11-12. Müellif, Tevhîd-i Bârî adlı kasidesinde de mümkün varlı̆̆ın yaratma sıfatına haiz olmadığını, dolayısıyla âlemin yaratıcısının bir zorunlu varlık olduğunu dile getirirken "mücerred müstakil bir vâcibin âsârıdır âlem-ki yoktur mümkünün yekdiğeri îcâda rüçhanı" ifadelerini kullanır. Ardından bu hükmün aslında özel olarak ispatına gerek olmadığını, zira herkesin şahsi vicdanının zaten bu hükmü vereceğini belirtir. Bk. Çerkeşşeyhizâde Mehmed Tevfik Efendi, Kasâid-i Tevfik (İstanbul: Mihran Matbaası, 1304), 5.

81 Cemal Kurnaz, “Sırrı Paşa”, Türkiye Diyanet Vakfi İslâm Ansiklopedisi (Ankara: TDV Yayınları, 2009), 37/128.

82 Sirrı Girîdî, Nakdü'l-Kelâm fí Akâidi'l-İslâm (Konstantiniyye: Matbaa-i Ebu'z-Ziyâ, 1302), 52.

83 Çerkeşşeyhizâde Mehmed Tevfik Efendi, Nakdü'l-kelâm fí akâidi'l-islâm kitabının tenkîd ve tashihi (İstanbul: Mahmut Bey Matbaas1, 1308), 222-223.

84 Manastırlı İsmail, Telhîsü'l-kelâm, 42-43.

85 Sırrı Girîdî, Nakdü'l-Kelâm fì Akâidi'l-ìslâm, (Dersaadet: Babıali Caddesinde 52 Numaralı Matbaa, 3. Basım, 1324), 52. 


\subsubsection{Diğer Tevhîd Delilleri}

Çerkeşşeyhizâde, başka bir kısım tevhîd delillerine de yer verir. Nitekim o farklı iki mülk üzerindeki ilah taaddüdünü reddederken bunun bir örneğini sunarak onun imkânsızlığını gerekçesiyle aktarır. Buna göre ilgili durumda onlar birbirlerinden kendi mülklerini gizlemeye ya güç yetirirler yahut yetiremezler. Şayet ilk seçenek gerçekleşirse, ikisinin de cehaleti; ikinci ihtimal vuku bulursa bu kez de acziyetleri ortaya çıar. Eğer onlardan biri bu gizlemeye kadir olur diğeri olmazsa, birinin cehalet ve acizlik ile nitelenmesi gerekir. Bütün bu üç seçeneğin gerektirdiği durumlar batıl olunca, ilahın tek olduğu ortaya çıkar. ${ }^{86}$ Osmanlının son dönem âlimlerinden Süleyman Sırrı da ilgili akaid risalesinde tevhîd delillerini aktarırken bu kanıta yer verir. Ancak onu Çerkeşşeyhizâde gibi "iki mülk üzerinde" şeklinde bir kayda tabi tutmaz. Doğrudan birden fazla ilahın varlığı halinde ilgili cehalet ve acizlik seçeneklerine atıfta bulunarak ilahın bir olmasının zorunluluğuna işaret eder. ${ }^{87}$

Çerkeşşeyhizâde, yine varlığı zorunlu olan Allah'ın bir ortağı olması halinde ortaya çıacak bir başka açmaza işaret ile de O'nun birliğini ispata çalışır. Buna göre başka bir ilahın varlığını reddedip Kendi birliğini ortaya koyan Allah karşısında o farazi ortağın kitaplar indirip peygamberler göndererek âlemin hükümranlığı hususunda O'na ortak olduğunu kullara bildirmesi gerekir. Hâlbuki böyle bir durum ortaya çıkmamıştır. Şayet böyle bir isteği olmasına rağmen o farazi ortak, suskunluğu tercih etmiş ise bu durum ya kendisinin acizliği ya da birliğini ortaya koyan Allah'ın sözünü tasdik etmesi nedeniyle gerçekleşmiştir. Her iki ihtimal de onun Allah'a ortak olmadığını gösterir ve Cenâb-1 Hakk'ın birliğini ispat eder. ${ }^{88}$ Müellifin zikrettiği bu delilin, onunla çağdaş olup aynı alanda eser kaleme alan diğer Osmanlı ilim ehlinde pek de görülmemesi kendisinin bu kanıta özel ilgi duyduğunu ihsas etmektedir.

Çerkeşşeyhizâde'nin zikrettiği bu son delilin ilk bölümünde İmâm Mâtürîdînnin (öl. 333/944) kullandığı bir delile başvurduğu, en azından ondan esinlendiği görülmektedir. Müellif tarafından her ne kadar burada ismi anılmasa da Mâtürîdî, "Âlemin var edicisinin bir olması meselesi” başlığı altında bu kanıtın temelini zikretmektedir. Buna göre ilgili mucizelerle gelen peygamberlerin ortaya koyduğu hususlarla ulûhiyet/leri boşa çıkan varlık/ların devreye girip bu duruma engel olması gerekirken, böyle bir işin vuku bulmaması ilahın bir ve tek olduğunu gösterir. ${ }^{89}$

Müellif, Miftâhu'l-akâid adlı eserinde de tevhîd meselesine değinirken onunla ilgili bir delil aktarır. Önce varlı̆̆ı zorunlu bir varlığın gerekliliğini ortaya koyar. Ardından böylesi bir varlığın neden birden fazla olamayacağı hususunu izah etmeye başlar. Buna göre şayet birden fazla ilah olursa, bu iki ilahtan biri diğerinden ya eksik olur ya da bu ikisi kuvvet ve kudret açısından birbirine denk olur. İlk ihtimal çok açık bir şekilde batıldır. Zira Allah,

86 Çerkeşşeyhizâde, Meziyyet-i İslamiyye, 12; Çerkeşşeyhizâde, Miftâhu'l-akâid, 10. Müellif, ilahların birden fazla olduğuna inanan kişilerin müşrik olarak adlandırıldıklarını belirtir. Bk. Çerkeşşeyhizâde, el-ittkân fî tahkîki'l-îmân, 32.

87 Süleyman Sırrı, Kenzü'l-akâid, 45.

88 Çerkeşşeyhizâde, Meziyyet-i İslamiyye, 10-11.

89 Ebû Mansûr Muhammed b. Muhammed b. Mahmûd el-Mâtürîdî, Kitâbü't-Tevhîd, thk. Bekir TopaloğluMuhammed Aruçi (Beyrut: Dâru Sâdır-İstanbul: Mektebetü'l-İrşad, ts.), 86. 
nakıs; nakıs Allah olamaz. Eğer kuvvetleri birbirine denk olursa, bunlardan her birinin varlığı diğerinden müstağni olur. Kaldı ki bunun gereğine dair kati bir delil de sunulamaz. Böyle eşit iki ilahın varlığı halinde âlem ya asla varlık alanına çıkmaz. Ya da bunlar âlemi yaratmak isterler ve bu hususta birleşirlerse aralarında mutlaka bir vakitte ihtilaf gerçekleşir. Bu durumda ise kainatın nizamdan çıkması ve onun bir kaos içerisinde kalması gerekir. Hâlbuki âlem işleyişi itibariyle başlangıçta nasılsa bugün de aynı şekilde bir düzensizliğe düşmeden akıp gitmektedir. Dolayısıyla bir mülk üzerinde iki ilahın varlığı gibi bir durum söz konusu değildir..$^{90}$

Çerkeşşeyhizâde tevhîd kasidesinde de benzer vurguları yapar. Buna göre birden fazla ilah olması halinde ya âlemin varlığı ortaya çıkmaz. Faraza bir âlem varlık alanına çıksa dahi o, keşmekeş içerisinde darmadağın bir vaziyette kalır. Kâinatta bir düzenin olması için ulûhiyette tevhîd olması gerekir. ${ }^{91}$ Müellif, kasidesinin bir beytinde bitkilerin ve cansız varlıkların çarpıcı bir şekilde Allah'ın birliğine delalet ettiğini söylerken de yine düzen ile O'nun vahdaniyeti arasında bir bağ kurarak benzer bir hususa dikkat çekmiş olur. ${ }^{92}$ Evrende pek çok şekil ve hareket bulunmasına rağmen orada müşahede edilen düzen ve ahengi vahdet üzerinden açılayan bir diğer kelâmcı da Filibeli Ahmed Hilmi'dir. ${ }^{93}$ Bu konuda Ömer Nasûhî de aynı minvalde bir izah geliştirir. ${ }^{94}$

\section{2. Çerkeşşeyhizâde'nin Tevhîde Aykırı Bazı Düşüncelere Bakışı}

Malum olduğu üzere genel anlamda tevhîdin zıddı şirk kelimesi ile ifade edilir. Şirkin de kendi içerisinde beş türü olup bunlardan birini “şirk-i esbâb” teşkil eder. Bu da eşyanın tabiatının gerçek müessir olduğuna inanılması suretiyle gerçekleşir. Tabiatçıların ve onların yolundan giden kimselerin içerisine düştükleri şirk çeşidi bu duruma örnek olarak sunulur. ${ }^{95}$ Isşte müellif, bu tasnife uygun şekilde Tabiatçıların konuyla ilgili görüşlerini tevhîd bahsinin hemen sonunda ele alarak, onların yaklaşımlarının tevhîde aykırı olduğunu gösterir. Mâtürîdî kelâmcı Sâbûnînin tevhîd konusunda İslam'a muhalefet eden grupların arasında tabiatçılara yer vermesi de, ${ }^{96}$ Çerkeşşeyhizâde'nin bu bakış açısında yalnız olmadığını göstermektedir.

Öte yandan Kur'an'da yer alan tevhîd âyetlerinden birinde Cenâb-1 Hakk'ın "Allah asla çocuk edinmemiştir. O'nunla beraber başka bir tanrı da yoktur; aksi takdirde her tanrı kendi yarattıklarını alıp bir tarafa çekilir ve mutlaka o tanrılardan biri diğerine baskın gelmeye çalışırd." (el-Müminûn 23/91) şeklinde hitapta bulunduğu bilinmektedir. Ayrıca baba, oğul ve kutsal ruh şeklinde üç uknum üzerinden savunulan teslis düşüncesinin ${ }^{97}$ de

\footnotetext{
90 Çerkeşşeyhizâde, Miftâhu'l-akâid, 9-10.

91 Çerkeşşeyhizâde, Kasâid-i Tevfik, 5.

92 Çerkeşşeyhizâde, Kasâid-i Tevfik, 3.

93 Şehbenderzâde Filibeli Ahmed Hilmi, Üss-i İslâm: Hakaik-i İslâmiyeye müstenid yeni ilm-i akaid (Darülhilafe: Hikmet [Matbaa-i İslâmiyesi], 1332), 32.

94 Ömer Nasuhi, Muvazzah İlm-i Kelâm, 152; Ömer Nasuhi, “Tevhîd-i Bârî”, Mahfil 5/59 (1343), 204.

95 İzmirli İsmail Hakk1, Yeni İlm-i Kelâm (İstanbul: Evkâf-1 İslâmiyye Matbaası, 1339-1341), 2/103; İzmirli İsmail Hakk1, el-Cevâbu's-sedîd fî beyâni dini't-tevhîd (Ankara: Tedkîkat ve Te'lifat-1 İslâmiye, 1339-1341), 17.

96 Ebû Muhammed Nuruddin es-Sâbûnî, Kitabü'l-bidâye mine'l-kifâye fi'l-hidâye fi usûli'd-din, thk. Fethullah Huleyf (Kahire: Dâru'l-Maârif, 1969), 39.

97 A. Hamdi Akseki, İslam Dini (Ankara: Diyanet İşleri Başkanlı̆̆ı Yayınları, 20. Basım, 1969), 65.
} 
şirk-i teb'îze örnek verildiği malumdur. ${ }^{98}$ İşte müellif bu ilahi kelâma ve söz konusu şirk çeşidine uygun şekilde tevhîd düşüncesine zarar verecek olan Allah'ın bir evladının bulunduğu fikrini de çeşitli açllardan ele alıp reddeder. O her ne kadar bu bahsi doğrudan tevhîd konusuna bağlı bir mesele şeklinde işlemese de onun tevhîde aykırı bir mevzu olduğu açıktır. Bu yüzden işbu konuya da yine tevhîde zıt düşünceler başlığı altında yer verilmesi uygun görülmüştür.

\subsubsection{Tabiatçı Anlayış}

Müellif, tabiatçıların âlemin kaynağı hakkında dile getirdikleri görüşleri ifade edildiği üzere tevhîd başlı̆̆ı altında inceler. O, akli delillerin gösterdiği şekilde bütün eşya Allah'ın varlık ve birliğini ortaya koyarken bu anlayış üzere olan kişilerin Yaratıcıyı tamamen inkâr ettiklerini belirtir. Ardından "eşhâs-1 rezile" tarafından savunulduğunu söylediği bu görüşü algıladığı şekilde aktarmaya başlar. Buna göre kâinatta gerçekleşen işler ilim, idrak, kudret ve kuvvetten uzak olup, cisim üzerinde kaim olan tabiatın külli ve nevî̂ (türsel) etkinlikleriyle vuku bulmaktadır. Bu fikri küfür, dalalet ve ahmaklığın en uç noktası olarak niteleyen müellif, onların ispat mevkiinde oldukları külli tabiatın; zorunlu, âlim, kâdir, ezeli, ebedi ve yüce bir zat olduğunu iddia ediyorlarsa, buradaki tek hatalarının isimlendirmede gerçekleştiğini söyler. Ancak burada nev î plandaki tabiat anlayışlarında ise hem müşrik hem de hulul görüşünün savunucusu konumuna düştüklerini ifade eder. ${ }^{99}$ Böylece derdinin isimlendirme hususunda değil, tek başına kadim olan bir varlığın kabulü noktasında olduğunu göstermiş olur.

Müellif Miftâhu'l-akaid isimli eserinde de tabiatçıların yanına bu sefer başka bir k1sım görüş sahiplerini de ilave ederek yine bu konuya temas eder. Bu manada aynı şekilde cehalet ve ahmaklık ile nitelediği ilgili görüş sahiplerinin Cenâb-ı Hakk'ın varlığını inkâr edip âlemdeki oluşumları, ilim, idrak ve kuvvetten uzak olan feleklerin hareketlerine, birtakım birleşimlere veya yıldızların teşekkülüne ya da eşyanın nevi tabiatına isnat ettiklerini belirtir. Ardından bu görüş sahiplerini niçin ilgili şekilde nitelendirdiğini ortaya koyan bir izah geliştirir. Buna göre eşyada tesir sahibi gerçekten söz konusu unsurlar olacak olsa, insanın mahiyeti ve cisimleri cisim yapan ilgili özellikleri hususunda bir eşitlik olması gerekir. Örneğin peşi sıra doğmuş ikizlerin, renk, şekil, nitelik, zekâahmaklık, cimrilik-cömertlik, korkaklık-cesaret, bedbahtlık-bahtiyarlık ve benzeri bütün zahiri ve batıni niteliklerde birbiriyle aynı olması gerekir. Zira hayat, ilim, kudret ve kuvvet sahibi olmayıp, bizzat kendisi oluşum ve yer tutmada bir illete muhtaç olan ilgili ilk üç unsur (hareket, birleşim, teşekkül), eşyalar karşısında sadece yeknesak bir etkide bulunabilir. Yine nevi tabiatın da bir maddede iki zıt fiili bir araya getirmesi söz konusu olamaz. Bu durumda ilgili örneklerde müşahede edilen zahiri ve batıni ayrılıkların gerçek müessiri ilim, kudret ve irade sahibi bir zorunlu varlık, yani Allah olmalıdir. $^{100}$

Müellif, Tevhîd-i Bârî adlı kasidesinde de Tabiatçıların düşüncelerinin yanlışlığına vurgu yapar. Buna göre tabiat, farklı eser vücuda getiremez. Bu ifadesiyle o, tabiatın tek

98 İzmirli İsmail Hakkı, Yeni İlm-i Kelâm, 103.

99 Çerkeşşeyhizâde, Meziyyet-i İslamiyye, 12.

100 Çerkeşşeyhizâde, Miftâhu'l-akâid, 19-20. 
düze işler ortaya koyabileceğini, âlemdeki farklılık ve zenginliklerin onunla izah edilemeyeceğine dikkat çekmiş olur. Nitekim aynı kasidenin bir başka beytinde cisim ve cismaniliğin izahında kullanılan tabiat kavramının belirsizlik içerdiğini söyler. Böylece kimilerinin düşündüğü gibi tabiatın âlemde etkin bir konumu olmadığını belirtmiş olur. Yine bir başka beytinde tabiatın müstakil bir varlığı olmayıp onun cevhere sirayet etmiş bir araz olduğunu, birbirinden farklı şekil ve renklere sahip bulunan varlıkların ondan sudur edemeyeceğini kaydeder. Aklı, ruhu ve kudreti bulunmayan bir tabiatın böylesi işleri düzenleyemeyeceğini belirtir. ${ }^{101}$ Müellifin, tabiatın aslında karşılı̆̆ı bulunmayan bir kavram şeklinde kullanıldığına dönük vurgusunun bir benzerini son dönem Osmanlı kelâmcılarının önemli simalarından Şeyhülislam Mustafa Sabri Efendi de (öl. 1954) sürdürür. ${ }^{102}$

Çerkeșşeyhizâde tabiatçı düşünceyi sadece âlemin ilahi güç tarafından yaratıldığını reddedip bu ilahi kudretin yerine tabiatı yerleştirmesi, dolayısıyla bir nevi şirke düşmesi nedeniyle eleştirmez. Tabiatçıların bilginin kaynağı hususunda sansualist (duyumcu) bir anlayış geliştirmelerine de tepki gösterir. Bu konuda Risâle fi'l-akl adıyla müstakil bir eser kaleme alan müellif, duyular olmadan aklın hiçbir anlam ifade etmediği, onun gerçekleştirdiği bütün idraklerde duyudan yardım aldığı şeklinde ortaya koyduğu yaklaşımı reddeder. ${ }^{103}$ Dile getirdiği mukaddimelere ve izahlara bağlı olarak insanın, kimi zaman dilimlerinde duyuların aracılığına başvurmadan sadece akıl vasıtasıyla bilgiye ulaştığı yönünde fikir beyan eder. ${ }^{104}$

Çerkeşşeyhizâde, tevhîd başlığı altında Tabiatçıların yaklaşımını açıladıktan sonra onların bu düşünceleriyle bir kısım kelâmcılar tarafından savunulan tabiatçı fikir arasındaki farkı da izah eder. Buna göre bazı kelâmcılar tabiatın etkinliği görüşüne yönelmişlerse de, diğerleri gibi Allah'ın varlığını inkâr edip, gerçek müessirin eşyada külli tabiat, kendilerinden zuhur eden fiil ve eserlerde ise nevi tabiat olduğu gibi bir fikre kapılmamışlardır. Bu kelâmcılara göre Allah her şeyi başlangıçta vasıtasız bir şekilde yaratmaya kadirdir. Bununla birlikte 0 , bir hikmetten ötürü bazı cisimlerde etkin bir tabiat yaratmış, böylece o cisimlerin kendilerinden zuhur eden fiil ve eserler o cisimlerin tabiatı gereği ortaya çıkar hale gelmiştir. Burada onlara göre Allah tarafından bazı cisimlere konulan müessir tabiatın yaratıcısı yine O olmaktadır. ${ }^{105}$

Müellif, bu konuda eşyada tabiatın etkinliği görüşünü savunan kelâmcıların, o tabiatın Allah tarafından yaratıldığı düşüncesini benimsedikleri için bunun sıkıntı oluşturmayacağına vurgu yaptıktan sonra çoğunluğu oluşturan kelâmcıların meseleye bakışını açılar. Buna göre tutuşmaya elverişli bir nesne ateşe atıldı̆̆ında onun yanması vasıtasız bir şekilde sadece ilahi kudret ile bu işlemi takiben ilgili eşyanın yanması ise âdet yolu ile gerçekleşmektedir. Bazı kelâmcılar ise o eşyanın ateşe atıldığında yanmasını, ateşte mevcut olan tabiatın etkisine bağlarlar. Ancak işaret olunduğu üzere onlar hem tabiat hem de

\footnotetext{
101 Çerkeşşeyhizâde, Kasâid-i Tevfik, 4-5.

102 Mustafa Sabri, Mevklfu'l-akl ve'l-ilm ve'l-âlem min rabbi'l-âlemîn ve ibâdihi'l-mürselîn (Beyrut: Dârü’t-Terbiye, 1427/2007), 3/340.

${ }^{103}$ Çerkeşşeyhizâde Mehmed Tevfik Efendi, "Risâle fi'l-akl”, Behcetü't-taraffi ilmi's-sarf(İstanbul: Mahmut Bey Matbaas1, 1308), 195.

104 Çerkeşşeyhizâde, "Risâle fil-akl”, 201-203.

105 Çerkeşşeyhizâde, Meziyyet-i İslamiyye, 12-13.
} 
onun etkinliğinin başlangıç itibariyle Allah'n yaratmasına bağlı olarak gerçekleştiğini düşünürler. Bu durumda eşyanın ateşte yanması yine Allah'ın bir fiili olup, bu iş sadece vasıtalı bir şekilde gerçekleşmektedir. Müellif, genel eğilimi ve azınlık görüşü bu şekilde aktardıktan sonra onlar hakkında bir hüküm de verir. Buna göre ikinci görüşte bir sıkıntı olması bir tarafa belki de o ilk yaklaşıma nispetle doğruya daha yakın bir düşüncedir. ${ }^{106}$ İzmirli İsmail Hakkı da her ne kadar diğerinden daha doğru olduğu yönünde bir vurgu yapmasa da bu son yaklaşımın şirk olmadığııın altını özellikle çizer. ${ }^{107}$

Çerkeşşeyhizâde, bu noktada ikinci anlayışın bir sıkıntı taşımadığına dönük görüşünü teyit için Fahreddin er-Râzî'den (öl. 606/1210) alıntı da yapar. Râzî, Bakara sûresi 2/22. âyetini tefsir ederken ilgili ifadesinde Allah'in meyveleri; su ve toprak gibi herhangi bir vasita olmaksızın yaratmaya kadir olmakla birlikte O'nun bu kudretinin, meyveleri söz konusu vasıtalarla yaratmasına bir engel teşkil etmediğini belirtir. Her iki durumda da O'nun yaratıcı ve hakîm olduğuna dikkat çeker. ${ }^{108}$ Çerkeşşeyhizâde, ilgili alıntıyı takiben yine Râzînin Felak sûresi 113/2. âyetinin tefsirinde kullandığ ifadelere de başvurur. İlgili bölümde Râzî, ateş, yılan veya akrebin ısırması sonucu oluşan acı hakkında kelâmcıların çoğunluğunun bunun doğrudan Allah'in yaratması ile gerçekleştiği yönünde görüş bildirdiklerini söyler. Filozofların çoğu ve kelâmcıların bir kısmı ise bu acıyı, ilgili varlıkların tabiatında Allah'ın yarattığı kuvveden doğan bir hal olarak açıkladıklarını kaydeder. Ardından bu ikinci görüşte bir beis olmadığı yönünde bir ifade kullanır ve Hz. Peygamber'in "Sen'den Sana sığınırım" ${ }^{109}$ hadisine yer verir. ${ }^{110}$ Çerkeşşeyhizâde, Râzî den yaptığı bu alıntıları takiben ilave bir izah getirmez ve böylece kimi tabiatçı kelâmcıların konuyla ilgili ifade ettikleri görüşlerinde niçin bir sıkıntı olmadığını Râzî üzerinden teyit etmiş olur."11 Yine müellif Tevhîd-i Bârî kasidesinde de eğer eşyada bir kabiliyetin bulunduğu ileri sürülürse bunun da Allah'in bir fiili olduğunu belirterek, bu düşüncenin çekinilmesi gereken bir görüş olmadığını ihsas etmiş olur. ${ }^{112}$

\subsubsection{Allah'a Bir Evlat İsnadı}

Çerkeşseyhizâde Miftâhu'l-akâid adlı eserinde Allah'a bir evlat isnadını da ele alır, böyle bir düşüncenin doğuracağı problemleri dile getirir. Öncelikle Allah'ın doğurmaktan münezzeh olduğuna dair hükmünü dile getirdikten sonra bunun gerekçelerini bir kısım ihtimallere yer vererek aktarmaya başlar. Buna göre eğer doğurmak ile bir nutfe söz konusu olmadan varlık alanına çikan bir çocuk kastedilirse, bir madde ve nutfe olmaksızın yaratılan yeryüzü, gökyüzü ve burada bulunan her şeyin de yine O'nun çocuğu olması gerekir. Bu ihtimalin batıllığı çok açık olduğu için onun hakkında bir değerlendirme yapmaya bile gerek yoktur. ${ }^{113}$

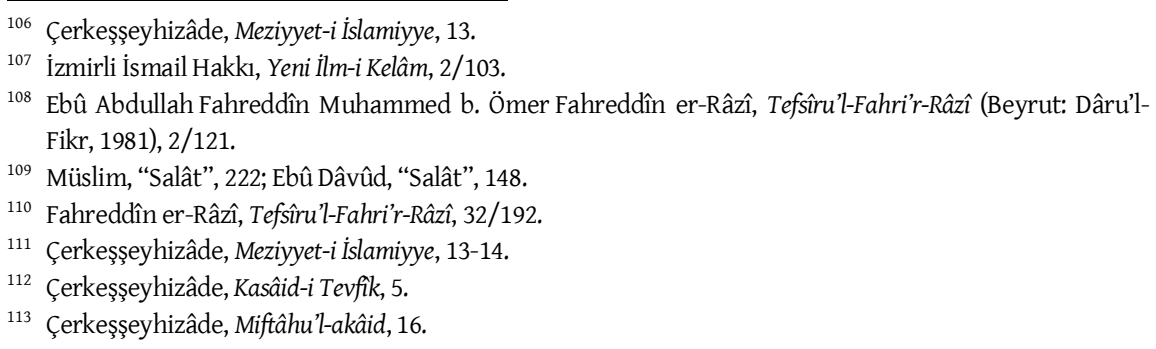


Müellif bu seçeneği takiben ikinci bir ihtimali daha ele alır ve onun yanlışlı̆̆ını da çeşitli ihtimaller ekseninde ortaya koymaya başlar. Buna göre eğer burada şehvetle ayrılan bir cüzün annenin rahminde yer almasına bağlı olarak ortaya çıkan bir çocuk kastedilirse, bu tip bir durumun; lezzet, şehvet, hareket ve kadınlarla yakınlaşma gibi halleri gerektirdiği bunların ise cisimlere ait özellikler içerisinde yer aldığı malumdur. Hâlbuki Allah ise cisimlik ve cismanilikten, dolayısıyla da söz konusu hallerden yücedir. Kaldı ki bu yoldan bir evlat edinme isteği; bir çocuk talep edip de onu maddesiz şekilde hemen yaratamayan aciz varlıklar için söz konusudur. Hâlbuki her istediğini her daim bir kerede maddesiz şekilde var etmeye kadir olan Allah için böyle bir durum düşünmek muhaldir. Yine bu seçenekte Allah için -hâşâ- bir lezzet ve şehvet giderme söz konusu olup, bu durumda eğer Cenâb-1 Hakk için bu iki hal tasavvur edilebilirse, O'nun bunlarla ezeli olarak vasıflanması gerekir. Bu ise o çocuğun da ezeli olmasını gerektirir. Hâlbuki anne karnına hapsolunduktan sonra ortaya çıkan çocuğun hâdis olacağı açıktır. Bu durum ise o çocuğun hem ezeli hem de hâdis olması gibi, herkesin batıllığını açıkça fark edeceği bir hale sebebiyet verir. Dolayısıyla böyle bir seçenek de doğru olamaz. ${ }^{114}$

Müellif, bu ikinci ihtimale (nutfe) bağlı olarak ortaya çıan açmazlara dikkat çekmeye devam eder. Buna göre yine Allah'ın ilgili surette bir evladı olması halinde, doğal olarak onun hâdis bir varlık olması gerekecek iken; bu aşamada O'nun her şeyi ezelde bildiği düşünüldüğünde o çocuğun Kendisi için bir olgunluk ve fayda olduğunu yahut olmadığını da ezelde bilmesi gerekir. Eğer ilk seçenek söz konusu olursa, o çocuğu ezelde yaratması gerekir. Bu ise, hâdis olduğu apaçık olan o çocuğun ezeli olmasını gerektirir. Böyle bir durum olamaz. Eğer burada ikinci ihtimal geçerli olursa, bu durumda Allah'ın o çocuğu asla var etmemesi gerekir. ${ }^{115}$

Müellif, yine bir nutfe üzerinden ortaya çıkacak çocuk düşüncesinin neden olduğu diğer problemlere değinmeyi sürdürür. Buna göre eğer o çocuk Allah'tan ayrılan bir cüze bağlı olarak ortaya çıktıysa; öncelikle o cüzün meni gibi bir madde olma ihtimali, o'nun böyle bir durumdan çok yüce olması itibariyle hemen devre dışı bırakılır. Bu cüzün ilim ve kudret gibi bir subuti sıfat olarak tasavvur edilmesi halinde ise; bu sıfat, O'nda ya baki olur ya da olmaz. Eğer baki olursa, bu durum bir sıfatın iki mahalde bulunmasını; eğer baki kalmaz ise bu sefer de Allah'ın ondan soyutlanmasını gerektirir. Her iki seçenek de açıkça batıl olduğundan böyle bir ihtimal de devre dışı kalır. ${ }^{116}$

Müellif, Allah'ın, Kendisinden ayrılan bir parçaya (cüze) bağlı olarak ortaya çıkacak çocuğun gerektireceği sıkıntılara temas etmeyi sürdürür. Buna göre bu parçanın ulûhiyette bir payı ya olur ya da olmaz. Eğer ilk durum söz konusu ise, o parçanın Kendisinden ayrılmasıyla O ya ilahlıktan tamamen soyutlanır ya da O'nun ulûhiyetinde eksilme meydana gelir. Eğer bu parçanın ulûhiyette bir payı olmazsa; o parçadan meydana gelen çocuğun asla Allah olmaması gerekir. Hâlbuki "evladın, baba cinsinden olması gerektiğgi" şeklindeki ifadeden hareketle o çocuğun da ilah olması lazımdır. Nitekim "De ki: 'Eğer Rahmanin çocuğu olsayd, ona tapanların ilki ben olurdum."'117 âyeti de bu hususa işaret

\footnotetext{
114 Çerkeşşeyhizâde, Miftâhu'l-akâid, 16-17.

115 Çerkeşşeyhizâde, Miftâhu'l-akâid, 17.

116 Çerkeşşeyhizâde, Miftâhu'l-akâid, 17-18.

117 ez-Zuhruf 43/81.
} 
etmektedir. ${ }^{118}$ Bütün bu ihtimallerin doğurduğu sıkıntılardan, Allah'ın bir evladının olmadığı anlaşılmaktadır.

Erzurumlu İsmail Hakkı'nın itikada dair manzum risalesini şerh eden ve müellifimizin (Çerkeşşeyhizâde) çağdaşı olup ondan bir sene sonra vefat eden Musacalızâde Mehmed Said Efendi de (öl. 1902) Allah'ın bir oğlunun olması halinde ortaya çıacak açmaza dikkat çekerken bu son maddeye yer verir. Buna göre Allah'ın bir evladı olması halinde o çocuğun O'nun cinsinden olması veya pederine yardım etmesi için talep edilmesi ya da O'na Kendisinden sonra halef kılınması gibi bir durum gerekir. Hâlbuki hiçbir varlık O'nun mücanisi (aynı cins özellikleri gösteren) bir fert olamaz. Zira Allah vâcibü'l-vücud, diğerleri ise mümkün varlıktır. Yine O'nun hiç kimsenin yardımına da ihtiyacı yoktur. O, ebedi olup Kendisine yokluk erişmeyeceği için halefi de söz konusu olamaz. İşte bütün bu yönler dikkate alındığında O'nun için bir evlat tasavvur edilemez. ${ }^{119}$

Çerkeşşeyhizâde, ilgili surette meydana gelen çocuğun doğuracağı başka bir açmaza daha işaret eder. Buna göre bu çocuğun varlığı ya zorunlu (vâcibü'l-vücûd) ya da mümkün olacaktır. Eğer ilk durum söz konusu olursa; kendisinin bir ilahın tesirine ihtiyaç duymaması gerekir. Dolayısıyla aralarında babalık-evlatlık ilişkisi imkânsız olur. Eğer ikinci ihtimal devreye girer de o çocuk mümkün kategorisinde olursa; varlığı Allah'ın yaratmasına bağlı olarak ortaya çıkacağı için onun Allah'ın oğlu değil, diğer mümkün varlıklar gibi bir varlık olması gerekir. Bu durum ve ortaya konulan diğer tüm ihtimaller imkânsız olduğuna göre, Allah'ın bir oğlunun olması da muhal olmuş olur. ${ }^{120}$

Müellif ilgili açmazlar üzerinden Allah'ın bir evladının olamayacağını ortaya koyduğu gibi, pek bir ayrıntıya girmeksizin O'nun doğmuş da olamayacağına dikkat çeker. Bu noktada doğumun bir hudûs işareti olduğuna işaret eden müellif, hem baba hem de evlat olmanın sonradan olmayı gerektirmesi itibariyle, Allah'ın böylesi eksiklik bildiren bu tür durumlar ile nitelenmesinin imkânsız olduğuna vurguyapar. ${ }^{121}$ Böylece Allah'ın birliği konusunda en çok öne çıkarılan ilahi zatın muhalefetün li'l-havadis sıfatına sahip olması, dolayısıyla hudûs işaretlerinden uzak bulunması şeklindeki özelliğine dikkat çekmiş olur. Musacalızâde de bu meseleyle alakalı olarak Allah'ın doğmuş kabul edilmesi halinde bu durumun O'nu sınırl, hâdis ve muhtaç bir varlık konumuna getireceğini söyler. Hemen ardından Allah'ın sonsuz, kadim ve hiçbir şeye ihtiyaç duymayan bir varlık olduğuna işaretle bu ihtimalin kabul edilemeyeceğine dikkat çeker. ${ }^{122}$

\section{Sonuç}

Osmanlı ilim dünyasının son dönemde yetiştirdiği önemli âlimlerden biri olan Çerkeşşeyhizâde Mehmed Tevfik Efendi, farklı sahalarda pek çok eser kaleme almış, bu manada kelâm alanında da muhtelif risaleler telif etmiştir. Kelâmın ince meseleleri hakkında muhtasar eserler ortaya koyup görüşler serdettiği gibi, onun temel konularına dair de fikirler üretmiştir. Onun, hakkında görüş beyan ettiği konulardan biri de İslam inanç esaslarının şüphesiz en önemli mevzularından birini teşkil eden tevhîd meselesi olmuştur.

\footnotetext{
118 Çerkeşşeyhizâde, Miftâhu'l-akâid, 18.

119 Musacalızâde Mehmed Said Efendi, Cevahirü'l-akaid (İzmir: Vilayet Matbaası, 1327/1911), 8.

120 Çerkeşşeyhizâde, Miftâhu'l-akâid, 18-19.

121 Çerkeşşeyhizâde, Miftâhu'l-akâid, 19.

122 Musacalıâde, Cevahirü'l-akaid, 8.
} 
İslam dünyasının ilmi geleneğine oldukça hâkim olduğu gözlenen, bu manada görüş bildirdiği çeşitli konularda klasik eserlerden muhtelif ibareler aktaran müellif, bu birikimine bağlı olarak savunduğu düşünceye dair güçlü veriler sunmuştur. Tevhîd meselesinde de bu özelliğini sergileyen müellif, eserlerinin risale tarzında olmasından dolayı konunun farklı boyutlarına çok fazla temas etmese de onunla ilgili muhtelif deliller ortaya koymuştur. Kelâm geleneğinde en çok kullanılan kanıtların başında gelen temânu' deliline özel bir önem atfetmiş, bununla birlikte başka delillere de yer vermiştir. Temânu' delilinin aktarımında klasik izah tarzını sürdürmüş, onun kesinlik bildirip bildirmediğine dair de yorum getirmiştir. Bu delilin birden fazla ilahın evrenin oluşumuna engel teşkil edeceği șeklinde değil onun kaos içerisinde kalacağı üzerinden ortaya konulması gerektiğine dikkat çekmiştir. Bu delil çerçevesinde getirdiği izahlar ile genel anlamda çağdaşı olduğu diğer Osmanlı kelâmcılarından daha zengin bir bilgi manzumesi sunmuş, ayrıca sistemli bir aktarım yolunu seçerek konunun anlaşılması hususunda önemli katkılar sağlamıştır.

Çerkeşşeyhizâde, Allah'ın varlığını ispat konusunda çokça yer verdiği vâcibü’l-vücûd kavramını farklı açılardan izah ettiği gibi, onu tevhîd delilinin önemli bir argümanı haline de getirmiştir. Daha çok İmam Mâtürîdî ile özdeşleşen ve bir ilah tarafından gönderilen nebinin diğer farazi bir ilah tarafindan engellenmemesi üzerinden ortaya konulan tevhîd deliline de yer vermiş, ancak bu aktarımında tamamen bu mezhep imamına bağlı kalmamıştır. Naklettiği diğer delillerde ise birden fazla ilahın kabulünü, bazı varsayımlar üzerinden ele almış, burada daha çok onların içerisine düşecekleri acizliğe dikkat çekmiş, kimi zaman ise ortaya çıkacak cehalet halini de bu duruma ilave etmiştir. Her iki niteliğin de bir ilahın şanına yakışmayacağı ilkesinden hareketle onun bir olması gerektiğine vurgu yapmıştır.

Tevhîdin zedelenmesiyle ortaya çıkan şirk çeşitlerinden birisi olan ve Tabiatçıların evrenle ilgili yaklaşımlarıyla özdeşleştirilen şirk-i esbâba da tevhîd delillerinin akabinde yer veren müellif, bu düşünceyi daha çok kâinatta bir yeknesaklığın bulunmaması, hâlbuki tabiat fikrinin bu duruma sebebiyet vermesi gerektiği hususundan hareketle reddetmiştir. Yine tabiat kavramının tam anlamıyla bir karşılığının bulunmamasını ve kendisine bir nevi var edicilik nispet edilen bu gücün akıl ve şuurdan yoksun olmasını da bu görüşün diğer bir zaafı olarak göstermiştir. Bu noktada işin içerisine ilk aşamada Allah'ı katarak tabiatçı bir fikri benimseyen kelâmclara değil bir eleştiri getirmek, onu doğruya daha yakın bir yaklaşım olarak görerek cesur bir tavır sergilemiştir. Tabii bunda Fahreddin er-Râzî gibi bir otoriteden destek alması da etkili olmuştur.

Müellif, Allah'a bir evlat isnadına bağlı olarak ortaya çıan ve tevhîd konusuyla olumsuz anlamda yakından alakası olan bu anlayışın getirdiği sıkıntılara da temas etmiştir. Burada onun ortaya koyduğu problemler daha çok ilgili varsayımın gerektirdiği huduslük işaretleri üzerine yoğunlaşmıştır. Bu manada kadim olarak kabul edilen bir varlığa yakıştırılan bu durumun neticesi olarak beliren cismanilik hallerinin, ilgili kabule aykırılık teşkil edeceği, üzerinde durulan önemli bir husus olmuştur. Burada ayrıca ilah için bir ihtiyacın belireceğine ve söz konusu çocuğun bu haliyle bir yönden ezeli bir yönden hâdis olma gibi bir açmaza sebebiyet vereceğine dikkat çekilmiştir. Bütün bu durumların içerdiği imkânsız hallere bağlı olarak da ilgili düşünce reddedilmiştir. 
Çerkeşşeyhizâde başta tevhîd delilleri olmak üzere konuya dair getirdiği açıklamalarla tüm Müslümanların ortak değeri olan bu ilkenin izahına zenginlik katmış ve sistemli bir görüş manzumesi sunmuştur. Kimi zaman eleştirel bir üslup benimseyen müellif, kimi zaman ise didaktik bir tarzda fikirlerini beyan etmiștir. Hem felsefeye hem de kelâm ilmine aşina olması, meseleleri açık ve ilmi bir muhteva içerisinde aktarmasına katkı sağlamıştır. Sahip olduğu ilmi birikim, kendisiyle çağdaş olan kimi zevatın eserlerinde yer aldığını düşündüğü hataları tashih etmesinin dahi önünü açmıştır.

Müellif, tevhid meselesiyle ilgiligenel itibariyle özgün fikirler ortaya koymayıp daha çok selefi olan ilim ehlinden istifade yolunu seçse de de mezkûr düşüncelerin ifade biçiminde bir özgünlük yakalamıştır. Yine konunun daha rahat anlaşılması için berrak bir dil eşliğinde bazı mukaddimelere yer vermesi, meramını okuyucuya aktarma hususunda başarı sağlamasına zemin hazırlamıştır. Kendi düşüncesine olan itimadı, aksi bir görüşün müdafii olan tabiatçıları ağır bir şekilde eleştirmesine; kimi İslam filozoflarını ise tekfir etmesine neden olmuştur. Buna karşılık İslami anlayış içerisinde hoş karşılanabileceğini düşündüğü kimi görüşlere ise oldukça 1lımlı yaklaşmıştır. Sonuç itibariyle o, daha çok risale tarzında kaleme aldığı eserlerinde, mensubu bulunduğu dinin temel öğretilerine sadakatle bağlı kalmış, tevhid konusunda da bu temel yaklaşımından taviz vermeyerek, onunla ilgili bir Müslümanın bilmesi gereken hususları açıklığa kavuşturmuştur.

\section{Kaynakça}

Akseki, A. Hamdi. İslam Dini. Ankara: Diyanet İşleri Başkanlığı Yayınları, 20. Basım, 1969.

Akyol, İbrahim. "Cerkesseyhîzâde Mehmet Tevfik Efendi ve Nef̂̂̀ye Nazîresi”. Çankırı Araştırmaları 1/1 (2006), 177-190.

Albayrak, Sadık. Son Devir Osmanlı Uleması 5 Cilt. İstanbul: Milli Gazete Yayınları, 1981.

Apaydın, Yasin. “Çerkeşşeyhîzâde Mehmed Tevfîk Efendi'nin Mâhiyetin Mec'ûliyeti Meselesine Dair Risalesi: İnceleme ve Tahkik”. Tahkik İslami İlimler Araştırma ve Neşir Dergisi 2/1 (2019), 1-30.

Arapkirli, Hüseyin Avni. “ilm-i Kelâm”. Dârülfünûn Dersleri. 1-192. İstanbul: İstanbul Dârülfünunu, 1331. Asım, Mustafa. Akaid Dersleri. Dersaâdet: Hilal Matbaası, 1324.

Atar, Aynur. Çerkeşizâde Mehmet Tevfik Efendi ve Akâid Risaleleri. Yüksek Lisans Tezi, Gümüşhane Üniversitesi, 2019.

Azamat, Nihat. “Çerkeşî Mustafa Efendi”. Türkiye Diyanet Vakfi İslâm Ansiklopedisi. 8/272-275. Ankara: TDV Yayınları, 1993.

Bardakoğlu, Ali. “Delâlet”. Türkiye Diyanet Vakfi islâm Ansiklopedisi. 9/119-122. Ankara: TDV Yayınları, 1994. Bilmen. Ömer Nasuhi. Muvazzah İlm-i Kelâm Dersleri. İstanbul: Evkâf-1 İslâmiyye Matbaası, 1339-1342. Bilmen, Ömer Nasuhi. “Tevhîd-i Bârî”. Mahfil 5/59 (1343), 202-205.

Bursalı, Mehmed Tahir. Osmanlı Müellifleri. 3 Cilt. İstanbul: Matbaa-i Âmire, 1333.

Çerkeşşeyhizâde, Mehmed Tevfik Efendi. Hudûsü'l-âlem. Atıf Efendi Kütüphanesi. 4657, 43b-44b. Çerkeşşeyhizâde, Mehmed Tevfik Efendi. el-ïtkân fîtahkîki'l-îmân. İstanbul: Âlem Matbaası, 1311. Çerkeşşeyhizâde, Mehmed Tevfik Efendi. Kasâid-i Tevfik. İstanbul: Mihran Matbaası, 1304.

Çerkeşşeyhizâde, Mehmed Tevfik Efendi. Meziyyet-i İslamiyye. Dersaâdet: Mahmud Bey Matbaası, 1307. Çerkeşşeyhizâde, Mehmed Tevfik Efendi. Miftâhu'l-akâid. İstanbul: Mihran Matbaası, 1301.

Çerkeşşeyhizâde, Mehmed Tevfik Efendi. Nakdü'l-kelâm fi a â̂idil'-íslâm kitabının tenkîd ve tashihi. İstanbul: Mahmut Bey Matbaası, 1308.

Çerkeşşeyhizâde Mehmed Tevfik Efendi, “Risâle fi'l-akl”. 195-203. Behcetü't-taraf fi ilmi's-sarf (ìstanbul: Mahmut Bey Matbaası, 1308.

Çerkeşşeyhizâde, Mehmed Tevfik Efendi. Risâle fi hakkifâkidi's-salât. İstanbul: Mahmut Bey Matbaası, 1308. Çerkeşşeyhizâde, Mehmed Tevfik Efendi. Risâle fîmahiyeti'l-mümkin ve'l-mec 'ûliyye. İstanbul: y.y., 1305. 
Çerkeşşeyhizâde, Mehmed Tevfik Efendi. “Tercüme-i Sahib-i Hal-i Divan”. Kasâid-i Tevfik. İstanbul: Mihran Matbaası, 1304.

Ebû Dâvûd, Süleyman b. Eşâs es-Sicistânî. es-Sünen. 5 Cilt. İstanbul: Çağrı Yayınları, 1981.

Eskişehrî, Mehmed Emin. Zübdetü'l-akâid. İstanbul: Süleyman Efendi Matbaası, 1298.

Filibeli, Şehbenderzâde Ahmed Hilmi. Üss-i İslâm: Hakaik-i İslâmiyeye müstenid yeni ilm-i akaid. Darülhilafe: Hikmet [Matbaa-i İslâmiyesi], 1332.

Girî̀î, Sırrı. Nakdü'l-Kelâm fi Akâidi'l-islâm. Konstantiniyye: Matbaa-i Ebu'z-Ziyâ, 1302.

Girîdî, Sırrı, Nakdü'l-Kelâm fî Akâidi'l-̇̇lâm. Dersaadet: Babıali Caddesinde 52 Numaralı Matbaa, 3. Basim, 1324.

Günaltay, M. Şemseddin. Felsefe-i Ûlâ: İsbât-ı Vâcib ve Ruh Nazariyeleri. Şehzadebaşı: Evkâf-1 İslâmiyye Matbaas1, 1339-1341.

Hacı Necib. Kenzü'l-feraid fi mesaili'l-akaid. Dersaadet: Kanaat Matbaası, 1335.

Hafız Kamil. Cevahirü'l- kelâm fi beyâni akaidi'l-İslam. Kastamonu: Matbaa-i Vilavet, 1334.

Harpûtî, Abdüllatif. Tenkîhu'l-Kelâm fî A kâid-i Ehli'l-̇̇slâm. Dersaâdet: Necm-i İstikbal Matbaası, 1330.

Haşim, Mehmed. Zübde-i akaid-i İslamiyye. İstanbul: Bâbıâli Caddesi 13 Numaralı Matbaa, 1319.

İbn Sinâ, Ebû AlîHüseyn b. Abdillâh b. Alîb. Sînâ. el-İsarat ve't-tenbihat. Thk. Süleyman Dünyâ. Kahire: Dâru'l-Maârif, 3. Basım, ts.

İnal, İbnülemin Mahmud Kemal. Son Astr Türk Şairleri. 12 Cilt. İstanbul: Milli Eğitim Basımevi, 1970.

İzmirli, İsmail Hakkı. el-Cevâbu's-sedîd fî beyâni dini't-tevhîd. Ankara: Tedkîkat ve Te'lifat-1 İslâmiye, 1339-1341.

İzmirli, İsmail Hakkı. Mülehhas İlm-i Tevhîd. İstanbul: Kanaat Matbaası, 1338.

İzmirli, İsmail Hakkı. Yeni İlm-i Kelâm. 2 Cilt. İstanbul: Evkâf-1 İslâmiyye Matbaası, 1339-1341.

Kubat, Mehmet. Kur'ân'da Tevhîd. İstanbul: Beka Yayınları, 2014.

Kurnaz, Cemal. "Sırrı Paşa”. Türkiye Diyanet Vakfi İslâm Ansiklopedisi. 37/127-129. Ankara: TDV Yayınlar1, 2009.

Manastırlı, İsmail Hakkı. Mevaidü'l-in'am fỉ berâhîni akaidi'l-İslâm. İstanbul: Şirket-i Sahafiye-i Osmaniye Matbaası, ts.

Manastırlı, İsmail Hakkı. Telhîsü'l-kelâm fỉ berâhîni akâidi'l-İslâm. İstanbul: Sırat-1 Müstakim Matbaası, 2. Basım, 1329.

Mâtürîdî, Ebû Mansûr Muhammed b. Muhammed b. Mahmûd. Kitâbü't-Tevhîd. Thk. Bekir TopaloğluMuhammed Aruçi. Beyrut: Dâru Sâdır-İstanbul: Mektebetü'l-İrşad, ts.

Mehmed Vehbi. Akâid-i Hayriye Tercümesi. İstanbul: Ahmed Kamil Matbaası, 1340-1343.

Musacalızâde, Mehmed Said Efendi. Cevahirü'l-akaid. İzmir: Vilayet Matbaası, 1327/1911.

Mustafa Sabri. Mevkıfu'l-akl ve'l-ilm ve'l-âlem min rabbi'l-âlemîn ve ibâdihi'l-mürselîn. 4 Cilt. Beyrut: Dârü’tTerbiye, 1427/2007.

Müslim, b. el-Haccâc el-Kuşeyrî. el-Câmiü’s-Sahîh. 3 Cilt. İstanbul: Çağrı Yayınları, 1981.

Natıkî, İbrahim. Risale-i akāidül-İslam. Dersaâdet: Matbaa-i Osmaniye, 1300.

Pakalın, Mehmet Zeki. Sicill-i Osmanî Zeyli. Haz. Mustafa Keskin vd. 19 Cilt. Ankara: Türk Tarih Kurumu, 2008.

Râzî, Ebû Abdullah Fahreddîn Muhammed b. Ömer Fahreddîn. Tefsîru'l-Fahri'r-Râzî. 32 Cilt. Beyrut: Dâru'l-Fikr, 1981.

Sâbûnî, Ebû Muhammed Nuruddin. Kitabü'l-bidâye mine'l-kifâye fi'l-hidâye fi usûlidd-din. Thk. Fethullah Huleyf. Kahire: Dâru'l-Maârif, 1969.

Sırrı, Süleyman. Kenzü'l-akâid. Dersaâdet: Ahter Matbaası, 1316.

Sırrı, Süleyman. Miftâhu'l-akâid. İstanbul: Mahmud Bey Matbaası, 1321.

Yıldız, Muhammet. Çerkeşizâde Mehmed Tevfik Efendi'nin Kelâmî Görüşleri. Yüksek Lisans Tezi, Karabük Üniversitesi, 2019.

Yücer, Hür Mahmut. “Bir İbn Arabî Müdafaası: Çerkeşîzâde Mehmed Tevfîk Efendi ve Levâyihu'l-Kudsiyye fî Fedâili'ş-Şeyhi'l-Ekber Adlı Eseri”. Tasavvuf: İlmî ve Akademik Araștırma Dergisi 9/21 (2007), 331-351. 